Historic, Archive Document

Do not assume content reflects current scientific knowledge, policies, or practices. 

62.73

\section{ROCK-GARDENS and Perennials}

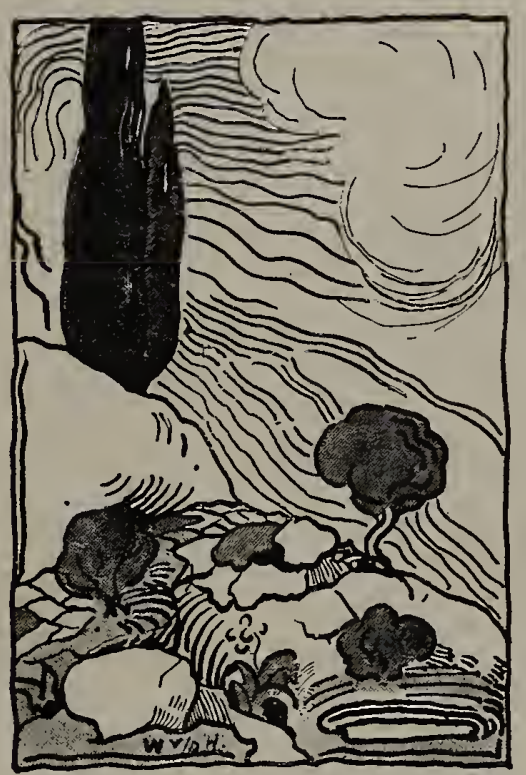

HENGEL BROS. 58-60 Lancaster Ave. ARDMORE, PENNSYLVANIA 


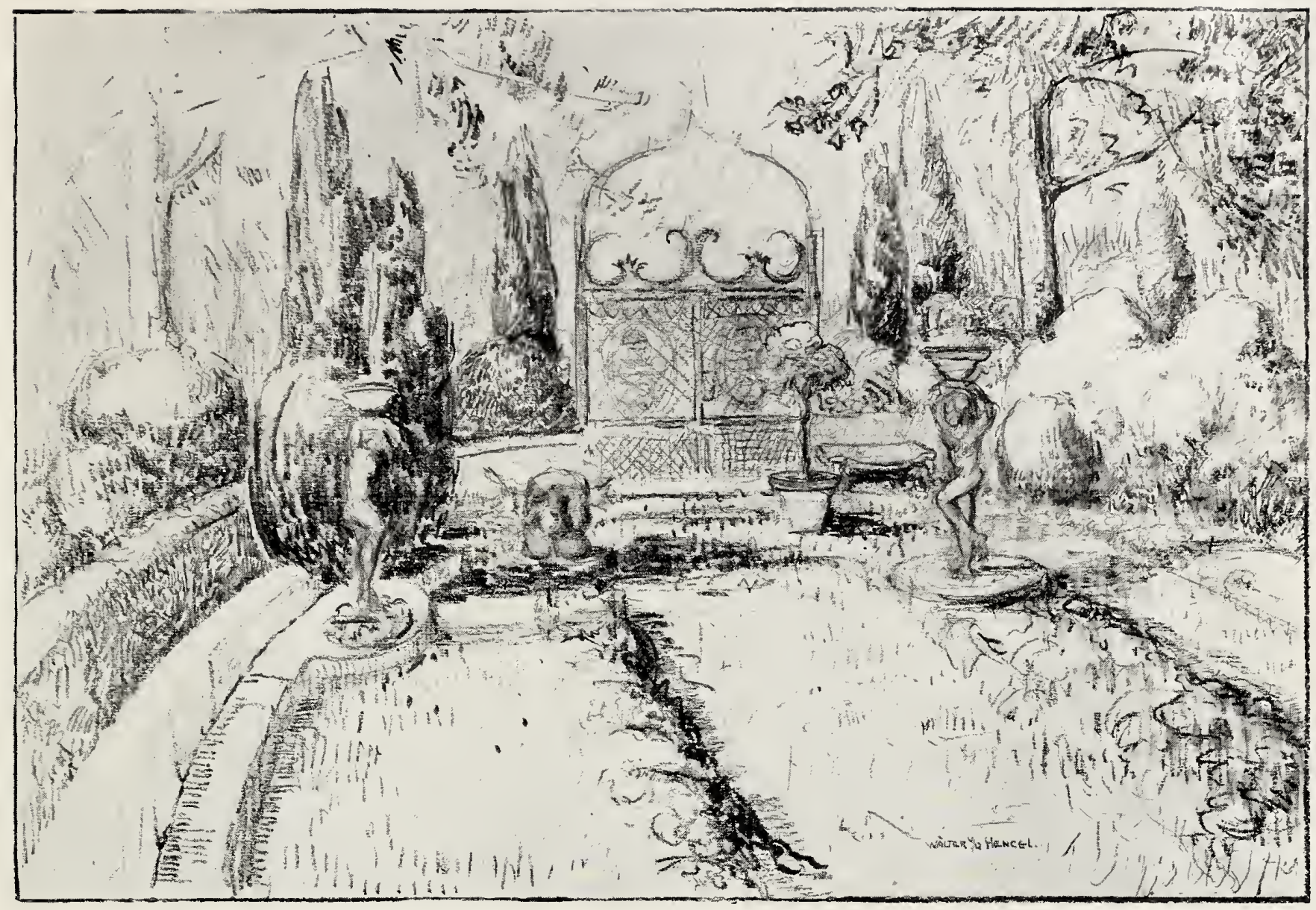

Garden design by Hengel Bros.

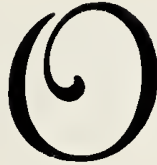

UR Catalogue has been planned and written to give the novice help and the more advanced gardener suggestions and reminders.

The plants have been grouped into different tables for varying purposes and positions. This often is a question when ordering or making up a list for a new planting of the garden in the spring. Every garden has its individual problems, and we are always ready to help and advise in aIl phases of garden making.

Our frrm has specialized in rock-gardens and other landscape features for many years. Our ideal is to follow boldly in the steps of Nature, making her ways our ways and capturing for you her many moods. Your garden is a part of your life which you enjoy in its most revealing moments; our satisfaction is these moments which we make possible for you.

We hope that this little book will give you the pleasure and profit which it is intended to offer, and assure you that all orders entrusted to our firm will receive our careful consideration.

You are invited to visit our Nurseries and Greenhouse on the road to Valley Forge, near the village called King of Prussia, Pa.

\section{HENGEL BROS., Ardmore, Pa.}




\section{$\widetilde{\sigma}$} open lawn or meadow which can be transformed into an open, rocky upland with a pool.

Second, the bordering edge of a woodland or tall shrubbery.

Third, a hillside or slight rise lends itself to a special kind of treatment very satisfying.

Those more fortunate, having a large space at their disposal, can perhaps use an approach to a woods through a gorge or little valley, making both sides of the winding way a constant joy.

The ugly scar left by an excavation for rock in building can be transformed into a sanctuary of peace and loveliness.

The cellar ruins of an old barn or house make most picturesque rock-gardens where the most delicate of alpines will thrive.

Natural outcroppings of rock, low Junipers of prostrate habit, and other taller ones, with a contrast in vivid colors, such as Pblox subulata, Aubrietia deltoidea, Saponaria ocymoides, and Primulas, are a combination that anyone can grow and enjoy. As you progress in your rockgarden adventure, you will want to try more difficult subjects, such as some of the rare

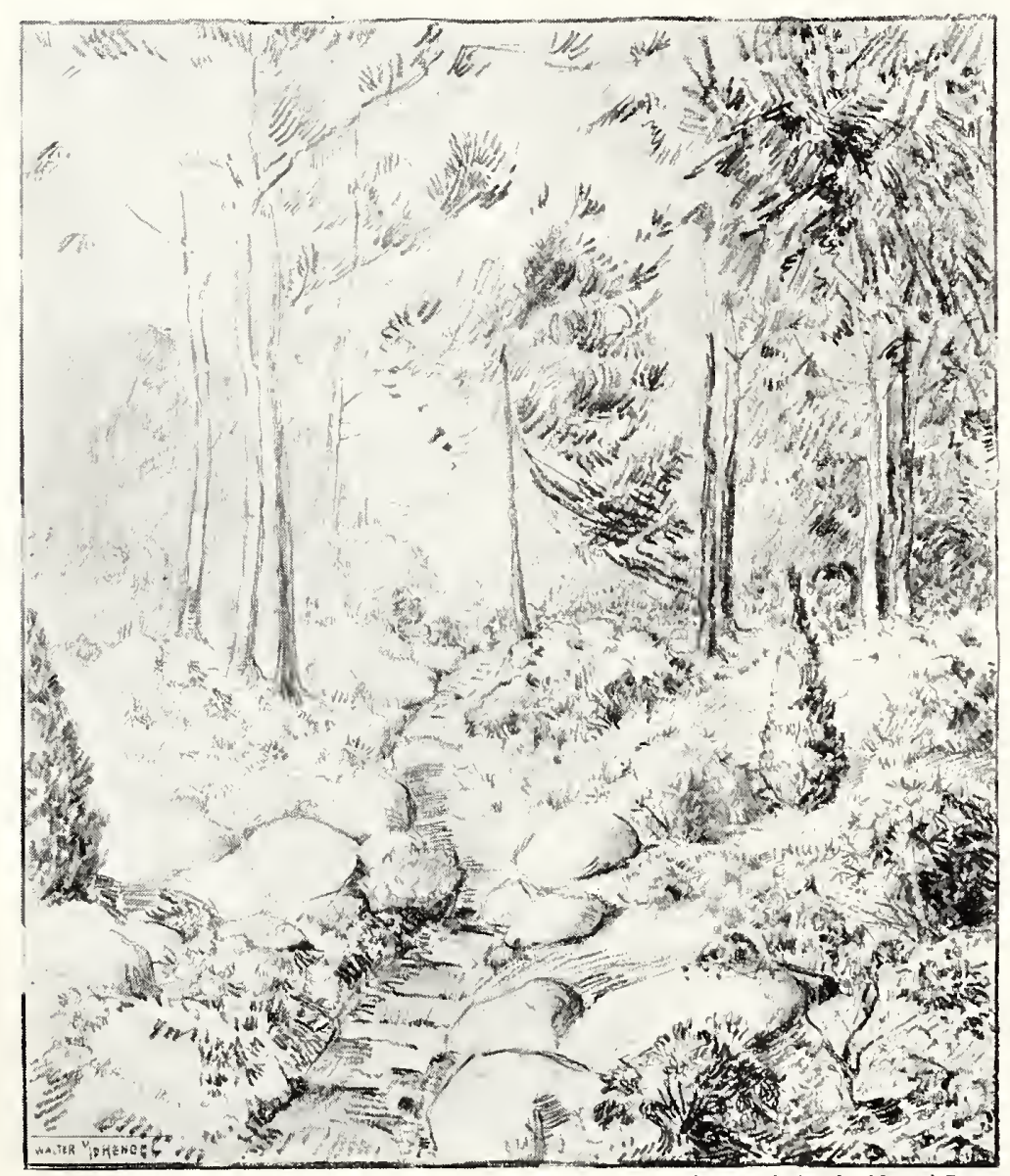

Garden design by Hengel Bros
Primroses, Campanulas, Ethionemas, Androsaces, Gentians, and innumerable other gems.

Water in some form, either a stream or pool, or low-lying, boggy ground-aIl can be incorporated in a rock-garden, for here we can simulate many periods of our earth's evolution and find denizens for each location, which will live happily and multiply for us. Here, also, a moraine can be constructed where many of the choicest alpines grow-Gentians, Primulas, and Campanulas.

The true alpine, intrepid, hardy, lives above the timber-line and right up to the snow, even sometimes appearing surrounded by snow. These are the gems we wish to grow and make happy in their make-believe home. Perfect drainage, clean, clear, cool air, and shelter from the hot sun of our summers, are the conditions necessary. All this can be accomplished if a rock-garden is properly constructed.

Arenaria formosa, Erinus alpinus, Globularia trichosanthes, Leontopodium alpinum, Lewisia pygmxa and $L$. rediviva, Primula frondosa, Sedum dasypbyllum, Dodecatbeon meadia, are only a few of the more precious varieties.

\section{General List of Hardy Plants for Rock-Gardens and Other Special Uses}

All plants in this list, 25 cts. each, $\$ 2.50$ per doz., unless otherwise noted

ACHILLEA filipendulina. Large, flat heads of yellow flowers and finely cut foliage. $4 \mathrm{ft}$. July and August.

Millefolium roseum. Rose-pink flowers in dense heads, on stems 18 inches high. July to October.

Ptarmica, Boule de Neige. An improvement on The Pearl.

Ptarmica, The Pearl. Pure white, double flowers. Good eutflower. $2 \mathrm{ft}$. June to September.

Tomentosa. Bright yellow flowers from June to September.

ACONITUM fischeri. Pale blue flowers in September. 35 cts. each; \$3 per doz.

Napellus, Sparks Variety. Dark blue. 35 cts. eacl ; \$3 per doz.

ETHIONEMA iberideum. Bushy plant with large showy white flowers. 35 cts. each; $\$ 3$ per doz.

Persicum. Charming little plant eovered with pink flowers. $35 \mathrm{cts}$. each; $\$ 3.50$ per doz.

Saxatile. A delightful variety with pale pink flowers. 50 cts. each; $\$ 5$ per doz.

Schistosum. Bushy habit. Beautiful rose-pink flowers in spikes. $50 \mathrm{cts}$. each; $\$ 5$ per doz.

AJUGA genevensis. Dense spikes of blue flowers in June. 30 cts. each; \$3 per doz.

Reptans. Deep purplish blue flowers.

ALYSSUM saxatile. Gray foliage. Clusters of bright mustardyellow flowers.

Saxatile compactum. The most popular of the Alyssums. Bright yellow flowers in April and May.

ANCHUSA italica, Dropmore Variety. Makes tall spikes of beautiful dark blue flowers, like giant forget-me-nots in June and July. 35 cts. each; $\$ 3$ per doz.

Italica, Opal. Like preceding, with Iustrous light blue flowers. 35 cts. each; $\$ 3$ per doz. 
Anchusa myosotidiflora. A dwarf variety of Anchusi, with clusters of eliarming blue flowers resembling forget-ne-nots. 30 ets. each; \$3 per doz.

ANEMONE hupehensis. Dwarfer than $A$. japonica, with similar flowers of dark rose-pink. $35 \mathrm{cts}$. each; $\$ 3.50$ per doz.

Japonica, Louise Uhink. Very large, pure white, double flowers. 50 cts. each; $\$ 5$ per doz.

Japonica, Max Vogel. Large, semi-double, light rose flowers. 50 cts. each: \$5 per doz.

Japonica, Richard Arends. Large, double, white flowers, tinted with pink. $50 \mathrm{cts}$. each; \$5 per doz.

Pulsatilla. Cup-shaped violet or purplish flowers in April and May. 30 cts. eacli; \$3 per doz.

Pulsatilla rubra. A reddish purple variety of the above. $30 \mathrm{cts}$. each; \$3 per doz.

AQUILEGIA alpina. The true dwarf Columbine from the Alps of Switzerland, with soft blue or blue and white flowers. Beautiful and very showy. $35 \mathrm{cts}$. each; $\$ 3.50$ per doz.

Canadensis. The bright yellow and scarlet native variety. Most attractive.

Chrysantha. A fine, bright yellow, long-spurred species of great beauty.

Flabellata nana alba. This is aIso a dwarf-growing variety with large, pure white flowers. 35 cts. each; $\$ 3.50$ per doz. Long-spurred Hybrids. Assorted light colors of the most attractive hybrid type.

Silver Queen. A pure white selection from the hybrids. Very lovely.

ARABIS alpina. Rock Cress. Pure white flowers produced in dense masses in April and May.

Alpina flore-pleno. A double-flowered variety of the above. $30 \mathrm{cts}$. each; $\$ 3$ per doz.

ARENARIA montana. A very pretty rock-plant, bearing its glistening white flowers freely during May. $30 \mathrm{cts}$. each; $\$ 3$ per doz.

ARMERIA maritima. Tufts of grass-like foliage, covered in May and June with purplish flowers. $30 \mathrm{cts}$. each; $\$ 3$ per doz.

Maritima alba. Tufts of grass-like foliage. Covered in May and June with white flowers. $30 \mathrm{cts}$. each; $\$ 3$ per doz.

Maritima Laucheana. Bright rose. $30 \mathrm{cts}$. each; $\$ 3$ per doz.

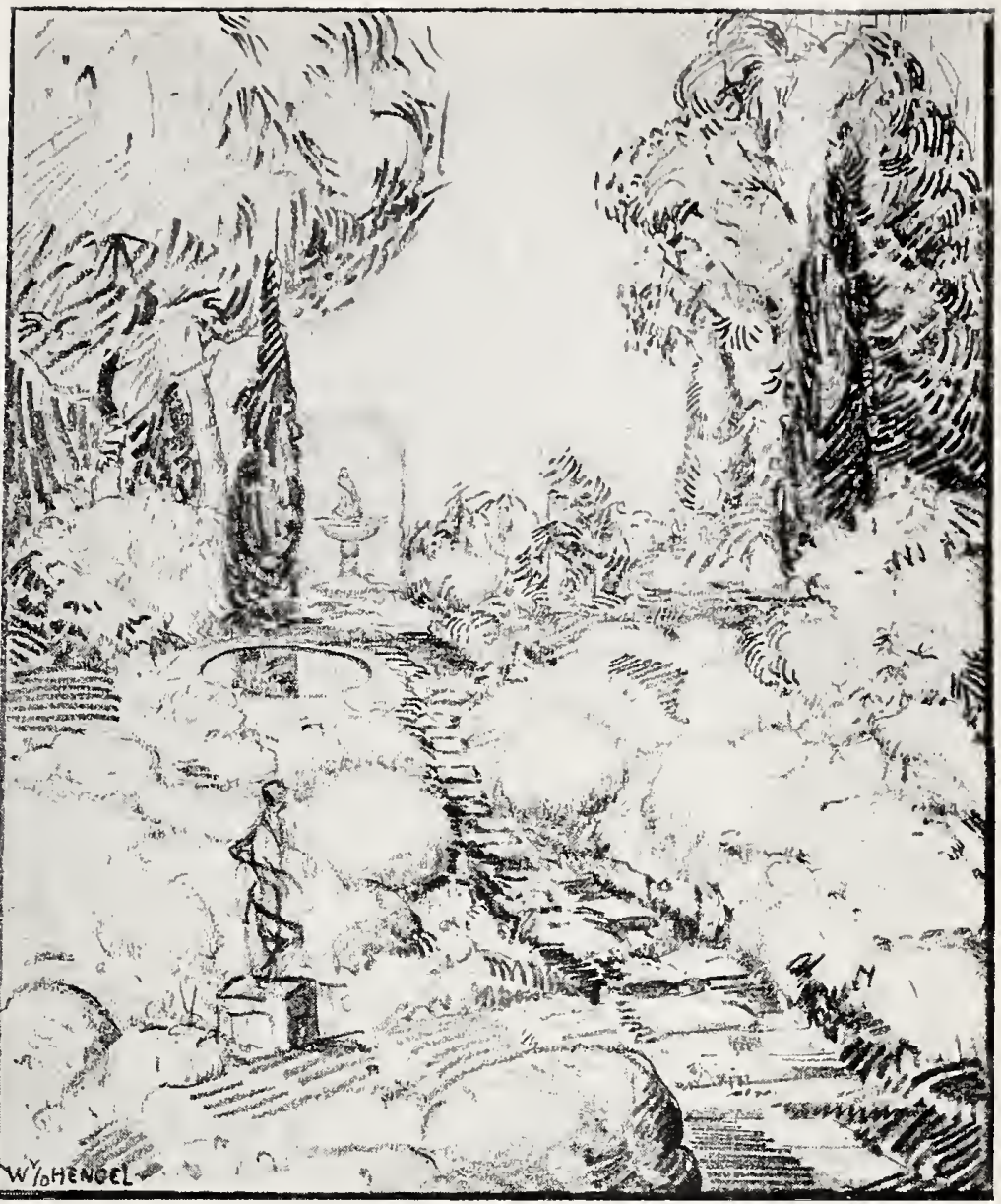

Garden design by Hengel Bros.

\section{Plants for Rock-Gardens}

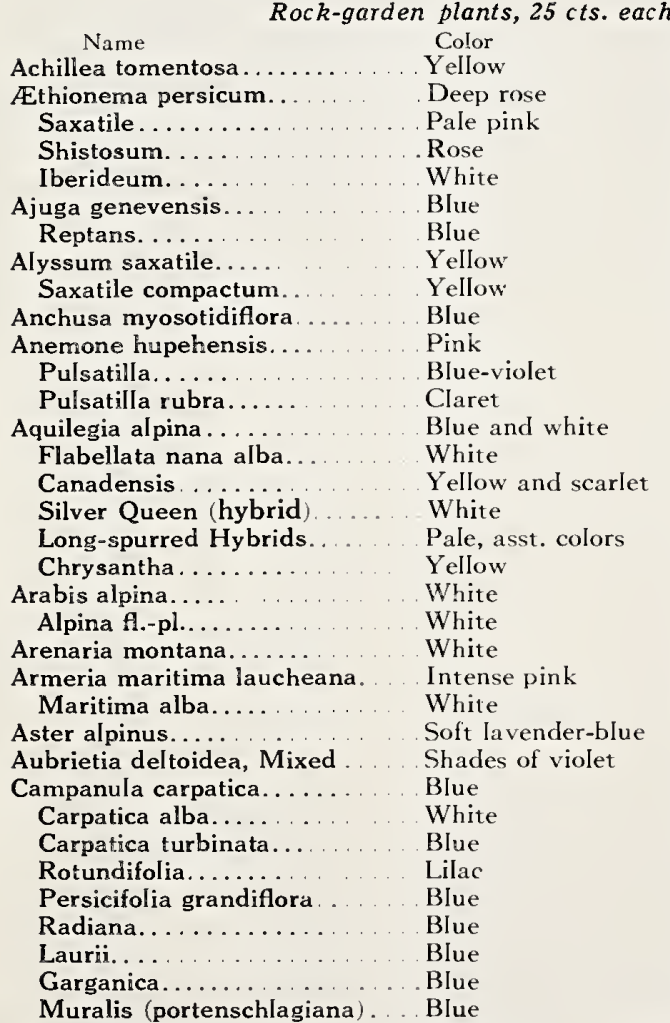

\begin{tabular}{|c|c|c|c|}
\hline & & & \\
\hline Height & Season & Soil & \\
\hline $8-10 \mathrm{in.}$ & June-Sept. & Sandy & \\
\hline 9 in. & June & Sandy & \\
\hline 9 in. & & & \\
\hline 9 in. & & & \\
\hline 9 in. & June & Sandy & \\
\hline $6-8$ in. & May & Good & \\
\hline $3-4$ in. & May, June & Good & \\
\hline 2 in. & ApriI, May & Sandy, well-drained & \\
\hline $2 \mathrm{in.}$ & April-June & Sandy, weII-drained & \\
\hline $0-12$ in. & May & Sandy leaf-mold & \\
\hline $8-12 \mathrm{in.}$ & Aug. & Sandy & \\
\hline $9-12$ in. & April, May & Rocky, well-drained & \\
\hline $9-12 \mathrm{in.}$ & April, May & Rocky, wel & \\
\hline $2 \mathrm{in.}$ & May, June & Moist, san & \\
\hline $8-10 \mathrm{in.}$ & June & Light, drai & \\
\hline $1-2 \mathrm{ft}$ & April-June & Good & \\
\hline $2 \mathrm{ft}$. & June & Goc & \\
\hline $2-3 \mathrm{ft}$ & June & Gor & \\
\hline $2-3 \mathrm{ft}$ & June & Goc & \\
\hline 6 in. & April, May & Goc & \\
\hline $6 \mathrm{in.}$ & April, May & Good & \\
\hline $6-8$ in. & May & Good & \\
\hline $3-6$ in. & April-June & Goor & \\
\hline $3-6$ in. & April-June & Goor & \\
\hline $3-10$ in. & May, June & Good & \\
\hline $2-10 \mathrm{in.}$ & May, June & Deep, ri & \\
\hline $9-10$ in. & June-Aug. & Rich, well-drained & \\
\hline $9-18$ in. & June-Aug. & Rich, welI-drained & \\
\hline $6-12 \mathrm{in.}$ & JuIy, Aug. & Rich loam, well-drain & \\
\hline $6-12 \mathrm{in}$. & June-Aug. & Rich, well-drained & \\
\hline $1 \mathrm{l} / 2-2 \mathrm{ft}$. & July & Rich & \\
\hline & & & \\
\hline $4-6$ in. & JuIy & & \\
\hline $4-6 i$ & May-Sept. & $\mathrm{Ric}$ & \\
\hline 4-6 in. & May, June & Rich loam, well-drained & \\
\hline
\end{tabular}

$\begin{array}{ll}\text { Position } & \text { Habit } \\ \text { Sunny } & \text { Tufts } \\ \text { Sun } & \text { Dwarf, shrubby }\end{array}$

Sun

Sun or shade

Sun or shade

un or shade

Sun or shade

Sheltered sun

Sun

n or shade

un or shade

artial shade

artial shade

Sun

Sun

Sun

Sun

Sun

un

Sun
Shrubby, dwarf

Spreading mats

Dense, creeping

Spreading habit

Compact

Clumps

Single plants

Single plants

Clumps

Clumps

Clumps

Clumps

Clumps

Clumps

Spreading

Spreading

Spreading

Cushions

Cushions

Branching

Spreading or I langing

Clumps

Clumps

Clumps

Clumps

Clumps

Spreading

Trailing, tuft y plant Trailing 


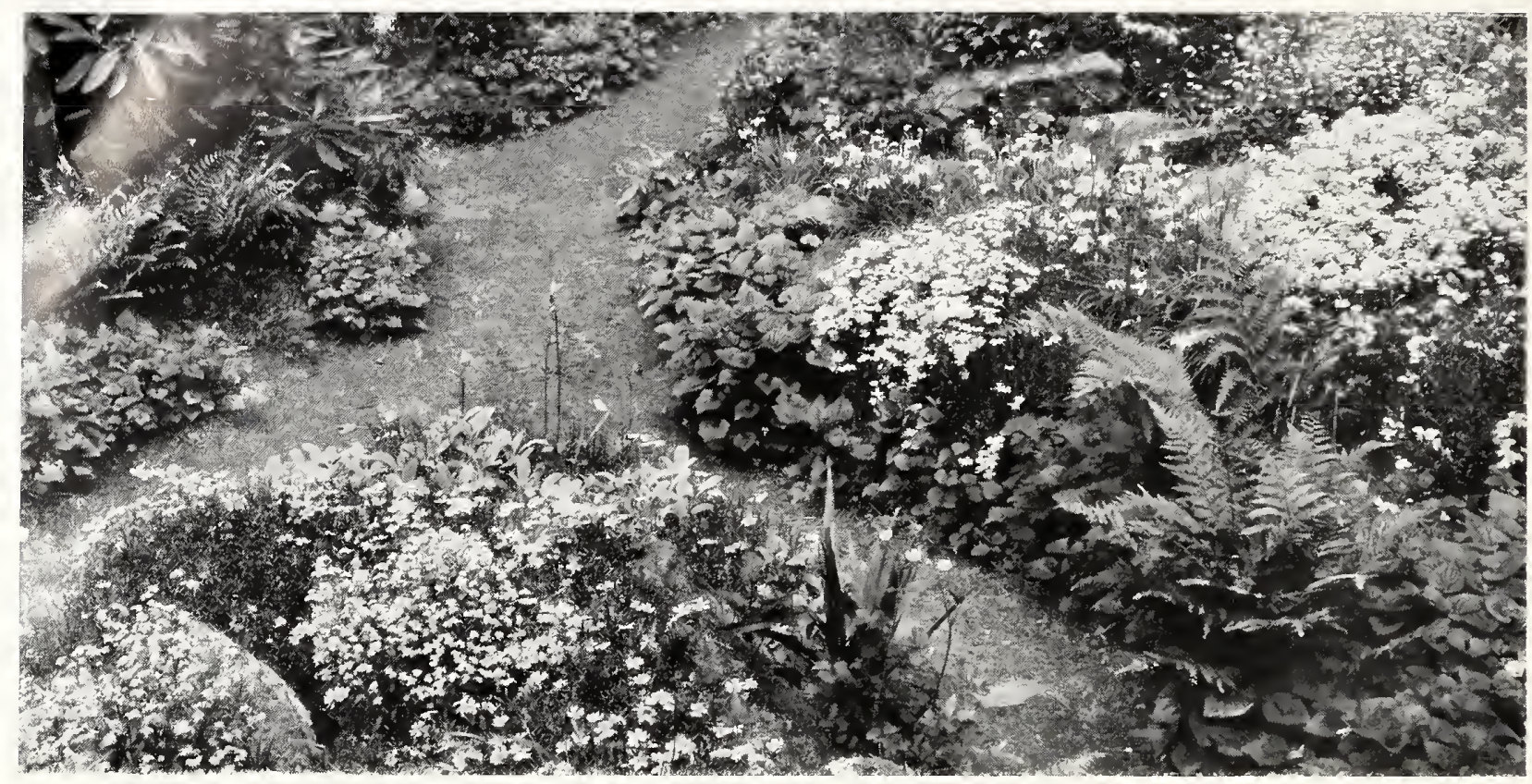

PLANTS FOR ROCK-GARDENS, continued from page 3

\begin{tabular}{|c|c|c|c|c|c|}
\hline Color & Height & Season & Soil & Position & Habit \\
\hline Calandrinia umbellata.......... Vivid magenta & $6 \mathrm{in}$. & June & Light & Sun & Single plants \\
\hline Caryopteris mastacantha......... Blue & $1-2 \mathrm{ft}$. & Scpt. & Good & Sun & Dwarf \\
\hline Cerastium tomentosum......... White & $3-6$ in. & June & Any (lime) & Sun & Trailing \\
\hline Cheiranthus allioni $\ldots \ldots \ldots \ldots$. Orange & $10-12 \mathrm{in.}$ & May-JuIy & Good (lime) & Sun & Erect \\
\hline Chrysanthemum arcticum ...... White & $8-10 \mathrm{in.}$ & Aug., Sept. & Good & Sun & Clumps \\
\hline Crucianella stylosa...........Pink & $6-9$ in. & June-Sept. & Sandy banks & Partial shade & Creeping \\
\hline Dianthus arenarius...........White, pur. center & $12-18 \mathrm{in.}$ & June, July & Rich, light & Sun & Erect \\
\hline Cresius............... Delicate pink & $8 \mathrm{in.}$ & May-July & Rich, sandy & Sun & Dwarf tufts \\
\hline Deltoides................ Crinıson & $6-9$ in. & May, June & Sandy & Sun & Dwarf \\
\hline Deltoides albus............. White & $6-9 \mathrm{in.}$ & May, June & Sandy & Sun & Dwarf \\
\hline Deltoides, Brilliant. .......... Crimson & $6-9$ in. & May, June & Sandy & Sun & Dwarf \\
\hline Dentosus. . . . . . . . . . . White or pink & 8 in. & June-Sept. & Sandy & Sun & Clumps \\
\hline Dicentra formosa........... Rose & $12 \mathrm{in.}$ & May, June & Leaf-mold & Partial shade & Clumps \\
\hline Eximia ................ Deep rose & $1-2 \mathrm{ft}$ & June-Aug. & Rich, sandy & Partial shade & Clumps \\
\hline Spectabilis.... . . . . . . . . . Rose & $1-2 \mathrm{ft}$. & April, May & Light, not too rich & Partial shade & Clumps \\
\hline Doronicum excelsum ......... Yellow & $12-18$ in. & May, June & Moist & Sun & Erect \\
\hline Erinus alpinus . . . . . . . . . . Violet and purple & $3-4$ in. & May, June & Well-drained & Sun & Tufts \\
\hline Erysimum Iinifolium ......... Mauve & $6-12$ in. & April, May & Light & Sun & Trailing tufts \\
\hline Pulchellum............. Yellow & $6-8 \mathrm{in.}$ & May, June & Well-drained & Sun & Trailing tufts \\
\hline Euphorbia polychroma ......... Yellow & $6-12$ in. & May, June & Light, drained & Sun & Bushy plants \\
\hline Geum, Lady Stratheden......... Yellow, double & $8-12$ in. & May-July & Good & Sun & Erect \\
\hline Gypsophila repens. ........... White & $6 \mathrm{in}$. & June, July & Fairly dry & Sun & Trailing \\
\hline Repens rosea.............. Pink & $6 \mathrm{in.}$ & June, July & Fairly dry & Sun & Trailing \\
\hline Helianthemum vulgare mutabile. White, pink, creanı & $8-12 \mathrm{in.}$ & June, JuIy & Sandy loam & Sun & Shrubby, low-growing \\
\hline Heuchera micrantha Hybrids. . . Pink and crimson & $12-18 \mathrm{in.}$ & May, June & Good & Sun & Clumps \\
\hline Sanguinea. . . . . . . . . . . . Crimson & $12-18 \mathrm{in}$. & May, June & Good & Sun & Clumps \\
\hline Hieracium villosum. . . . . . . . . Yellow & $1-2 \mathrm{ft}$ & June-Aug. & Good & Sun & Spreading clumps \\
\hline Hypericum polyphyllum. . . . . . . Yellow & $6-8$ in. & June-Aug. & Light, warm & Sun & Trailing sub-shrub \\
\hline Iberis sempervirens............White & $9-15$ in. & May, June & Good & Sun & Shrubby \\
\hline Sempervirens, Little Gem .... White & $12-18 \mathrm{in.}$ & May, Junc & Good & Sun & Dwarf \\
\hline Gibraltarica............. Pale Iilac & $12-15 \mathrm{in.}$ & May, June & Light & Sun & Shrubby,trailing lıbit \\
\hline Iris cristata. . . . . . . . . . Pale lilac & 4-9 in. & May-July & Light, well-drained & Sun & Dwarf \\
\hline Pumila . . . . . . . . . Deep violet & $4-9$ in. & May & Good & Partial shade & Dwarf \\
\hline Pumila, The Bride.......... White & $10 \mathrm{in.}$ & May & Any & Sun & Dwarf \\
\hline Sibirica orientalis ........... Blue & $12-18 \mathrm{in.}$ & June & Wet or dry & Sun & Species \\
\hline Leontopodium alpinum. ....... Silvery white & $6 \mathrm{in.}$ & June-Aug. & Lime & Sun & Tufts \\
\hline Linum perenne............. Pale blue & $12-15 \mathrm{in.}$ & June & Good & Sun & Erect \\
\hline Lychnis alpina ............ Pink & 6-8 in. & April, May & Sandy & Sun & Compact cushions \\
\hline Arkwrighti............. Pink to orange & $1-2$ in. & June, July & Good & Sun & Erect \\
\hline Mertensia virginica. . . . . Blue, shading pink & $1-2 \mathrm{ft}$. & April, May & Good & Sun or shade & Erect \\
\hline Myosotis palustris semperflorens. Blue & 6-8 in. & April, May & Moist, cool & Sun or shade & Creeping \\
\hline Nepeta mussini ........... Lavender & $10-12$ in. & June & Good (Iime) & Sun & Trailing \\
\hline Enothera missouriensis ....... Yellow & $8-10 \mathrm{in.}$ & May, June & Good & Sun & Procumbent \\
\hline Pachysandra terminalis......... Evergreen & 6-8 in. & Evergrecn & Good & Shade & Creeping \\
\hline Papaver alpinum. .......... White, yellow, orange & $5-6$ in. & Summer & Light & Sun & Tufted \\
\hline Nudicaule. .................... & $10-12$ in. & May, June & Light (line) & Sun & Erect \\
\hline Phlox amœena.............Magenta and paler & $4-6$ in. & April, May & Light & Dry & Trailing \\
\hline Divaricata canadensis......... Lavender and blue & $10-18$ in. & April, May & Good, rich & Sun & Erect \\
\hline
\end{tabular}




\section{Rock-Plants and Perennials}

ASPERULA odorata. Sweet Woodruff. Clusters of fragrant white flowers. Good shade plant.

ASTILBE. Sprays of foamy flowers in shades of cream and pink. Fine for moist, shady places. $75 \mathrm{cts}$. each.

ASTER alpinus. Alpine Aster. Bears Iarge, showy, bluish purple flowers in May and June.

Alpinus albus. A white variety of the above.

Subcæruleus. Forms dense tufts of leaves, from which rise numerous large violet-purple flowers on slender, erect stems in $\mathrm{June}$ and $\mathrm{July}$.

AUBRIETIA deltoidea, Mixed. This is, no doubt, one of the most beautiful subjects for the rock-garden or dry wall, forming a regular sheet of eolor for many weeks during April and May. The colors run through biue, pink, and lavender.

CALANDRINIA umbellata. A beautiful and striking subjeet for the rock-garden. The briliant flowers of a glowing crimson-magenta are produced in terminal clusters fron $J u n e$ on through the entire summer. $40 \mathrm{cts}$. each; $\$ 4$ per doz.

CALTHA palustris. Marsb Marigold. Bright sunny yeliow flowers on tufted piants. Fine for wet places.

CAMPANULA carpatica. Makes dense, round clumps about a foot across, with large, bell-shaped flowers of a clear blue color on erect, wiry stems from June till October. 30 cts. each; $\$ 3$ per doz.

Carpatica alba. Same as preceding, but white. $30 \mathrm{cts}$. each; $\$ 3$ per doz.

Carpatica turbinata. Very dwarf, with large, erect, bellshaped flowers of deep purplish blue. 30 ets. each; $\$ 3$ per doz.

Garganica. A trailing species and a gem for the rock-garden, with charming pale biue, purple, and white flowers. $50 \mathrm{cts}$. each; $\$ 5$ per doz.

Giant Harebell. A very pretty, slender-growing plant, with numerous bell-shaped blue flowers throughout the summer and autumn. $40 \mathrm{cts}$. each; $\$ 4$ per doz.

Latifolia macrantha. Grows 3 feet high, with enormous, deep purple, drooping bells in July.

Lauri. A slender-stemmed, ereeping variety with large, lavender-blue belis. Charming. $50 \mathrm{cts}$. each; $\$ 5$ per doz.

Muralis. A very dwarf-growing Campanula with purplish blue flowers in June. 40 cts. each; $\$ 4$ per doz.

Persicifolia. Peacb Bells. Tall spikes with drooping, blue, bell-like flowers.

Persicifolia grandiflora. One of the best Campanulas, with handsome foliage and strong, ereet stems 2 to 3 feet high, producing many large, clear blue bell-shaped flowers in June and July.

Persicifolia grandiflora alba. A white variety of the above.

Pyramidalis. This is the Chimney Bellflower, growing 4 to 5 feet high. It is a mass of beautiful blue-shaded lowers in the fall.

Radiana. A rather exquisite dwarf variety with spikes of rich purple flowers. $50 \mathrm{cts}$. each.

Rotundifolia. Low, matted plant with clusters of hilac-blue flowers on splendid, erect stems.

Trachelium. Sturdy plants, growing 2 to 3 feet high, with light purple flowers, in July and August.

CENTAUREA montana. Hardy Cornflower. Grows 2 feet high, with woolly foliage and large violet-blue flowers in June and July.

CERASTIUM tomentosum. Snow-in-Summer. An ideaI roekplant with silvery white foliage, producing an abundance of snow-white flowers in May.

CHEIRANTHUS allioni. Siberian Wallflower. A very beautiful plant, making a wonderful effect with its fiery orange flowers on stems about a foot high. Starts blooming in May, and if seed-pods are kept picked off regularly it keeps on until frost. 35 cts. each; $\$ 3.50$ per doz.

CHRYSANTHEMUM arcticum. Dark green, tufted plant, producing many large white flowers in autumn, sometimes tinged lilac and rose.

Hardy. Named large and small-flowered in varieties.

Maximum. Sbasta Daisy.

COREOPSIS grandiflora. Bright yellow, daisy-like flowers, borne on long slender stems throughout the summer, fine for cutting.

CRUCIANELLA stylosa. A pretty plant, making delicate masses with pink flowers early in the season. $30 \mathrm{cts}$. each; $\$ 3$ per doz.

DELIPHINIUM belladonna. The freest blooming Larkspur, with spikes of sky-blue flowers, from June until frost.

Beilamosa. Same as above, with dark blue flowers.

Chinense. A very pretty variety with finely eut foliage and intense gentian-blue flowers. $2 \mathrm{ft}$. June to September. Chinense album. A pure white form of the above.

HENGEL BROS., Ardmore, Pa.

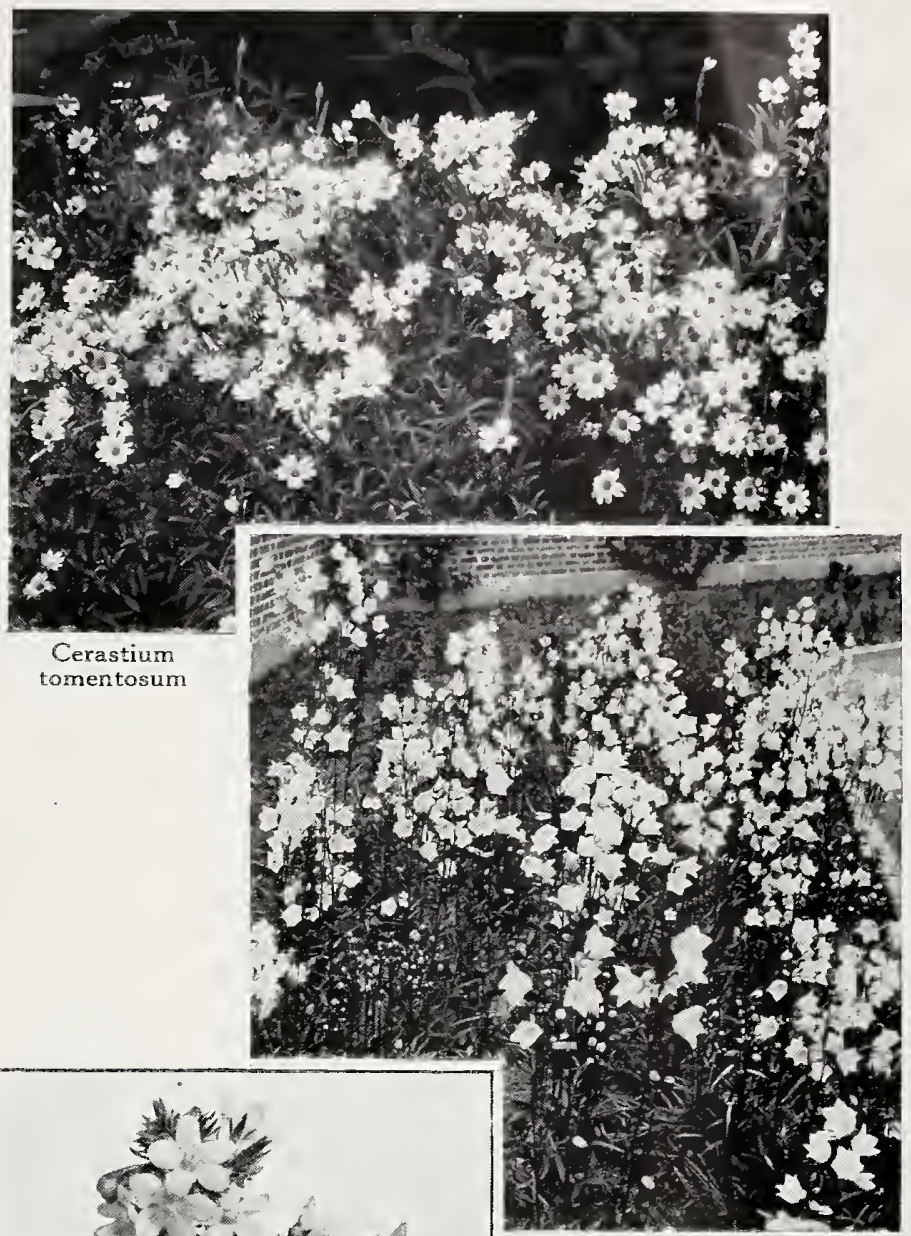

Campanula persicifolia

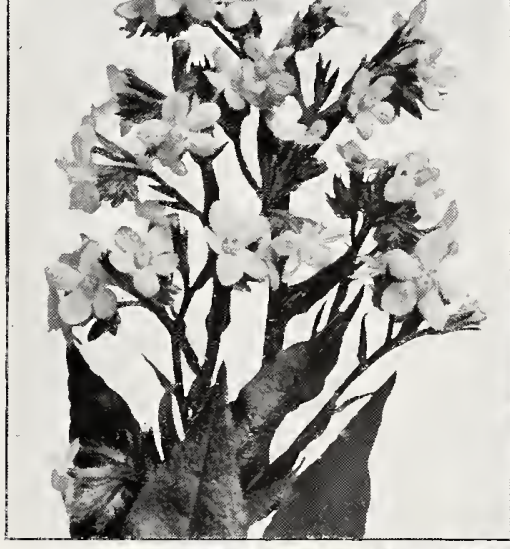

Anchusa

myosotidiflora

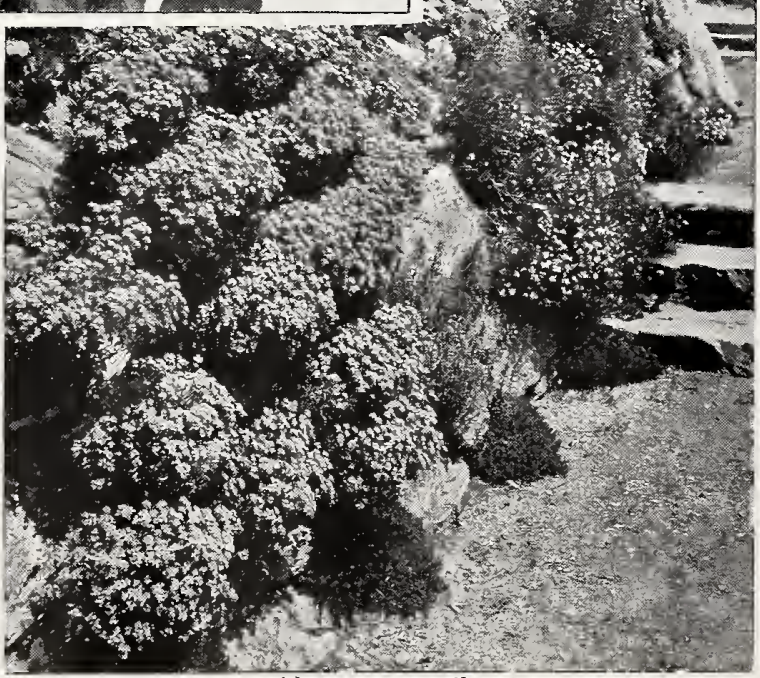

Alyssum saxatile

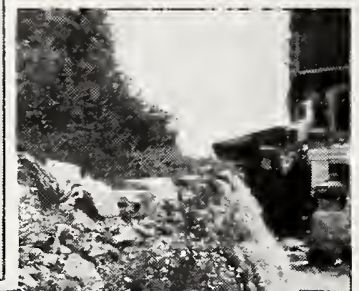

1] (1)

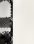




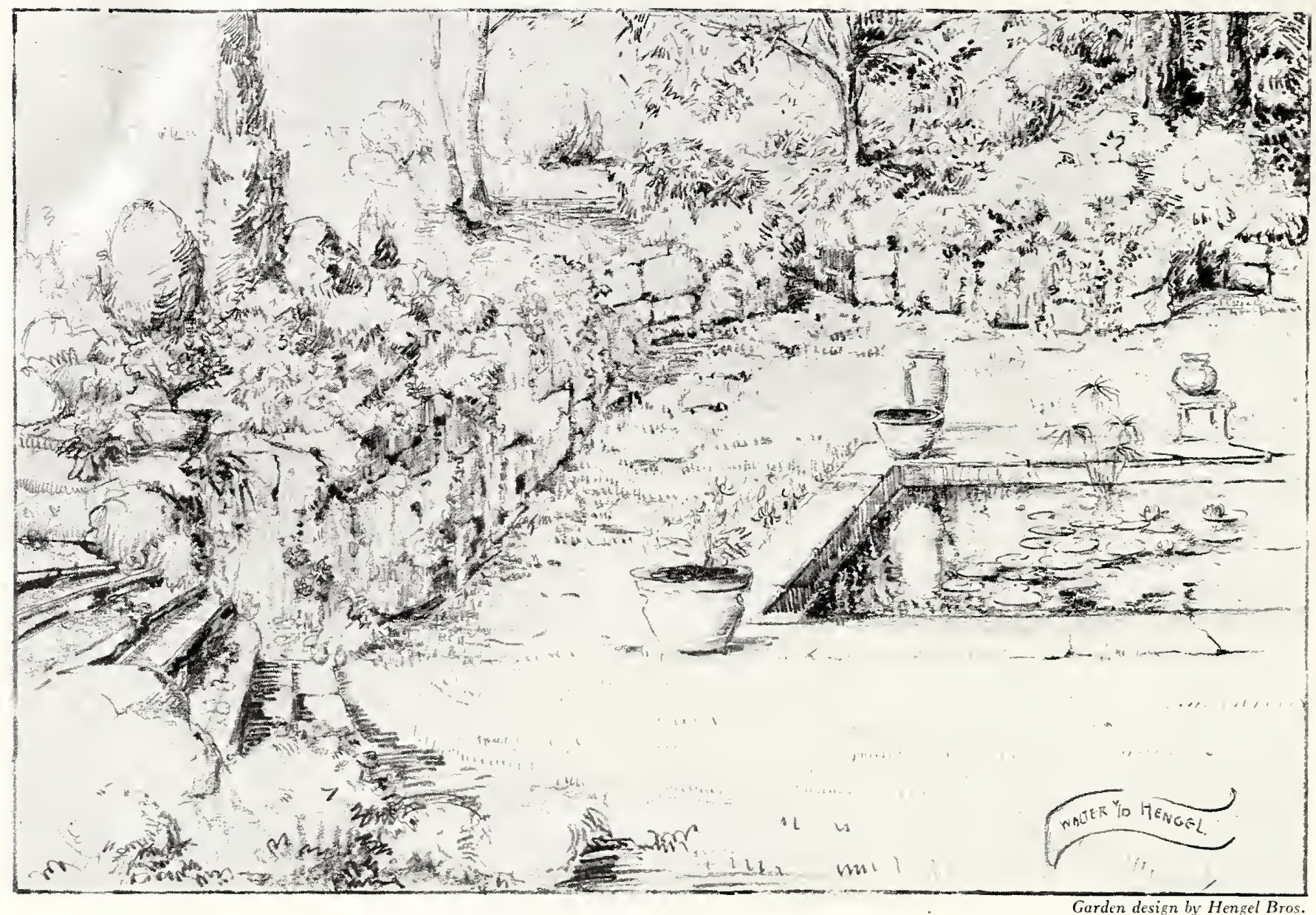

PLANTS FOR ROCK-GARDENS, continued from page 4

\begin{tabular}{|c|c|c|c|c|c|}
\hline Name & Height & Season & Soil & Position & Habit \\
\hline Phlox subulata alba ......... & $4-6$ in. & April, May & Light, dry & Sun & Creeping \\
\hline Subulata lilacina. . . . . . . . Lilac & $4-6$ in. & April, May & Light, dry & Sun & Creeping \\
\hline Subulata rosea. . . . . . . . . . . Rose & $4-6$ in. & April, Mav & Light, dry & Sun & Creeping \\
\hline Subulata, Vivid.............. Salmon & $46 \mathrm{in.}$ & April, May & Light, dry & Sun & Creeping \\
\hline Subulata, G. F. Wilson. . . . Shell-pink & $4-6$ iir. & April, May & Light, dry & Sun & Creeping \\
\hline Plumbago larpentæ ............ Blue & $6-12 \mathrm{in}$. & Aug., Sept. & Warm, light & Sun & Trailing, half shrubbery \\
\hline Polemonium reptans........... Blue & 4-6 in. & April, May & Rich loam & Partial shade & Dwarf, bushy \\
\hline \multicolumn{6}{|c|}{ Primula. See coniplete list of these under separate heading. } \\
\hline Ranunculus acris f.-pl......... Yellow & $1-2 \mathrm{ft}$ & May-Sept. & Moist loam & Sun & Creeping \\
\hline Santolina chamæcyparissus incana.Gray foliage & $1-2 \mathrm{ft}$. & All season & Good & Sun & Shrubby plant \\
\hline Saponaria ocymoides.......... Rose-pint & $6-8 \mathrm{in.}$ & May & Good & Sun & Trailing \\
\hline Sedum acre................ Yellow & $4 \mathrm{in}$. & May & Dry & Sunny & Creeping \\
\hline Album............... . White & $4-6$ in. & June, July & Sandy & Sunny & Creeping \\
\hline Hispanicum . . . . . . . . Pinkish white & $3-4$ in. & July, Aug. & Sandy & Sunny & Creeping \\
\hline Kamtschaticum. ........ Golden yellow & $4-9$ in. & July, Aug. & Sandy & Sunny & Creeping \\
\hline Lydium . . . . . . . . . . . & $3-6$ in. & Aug., Sept. & Dry & Sunny & Creeping \\
\hline Obtusatum............... Golden yellow & $3-6$ in. & June & Dry & Sunny & Creeping \\
\hline Sexangulare............. Yellow & $3-6 \mathrm{in.}$ & June, July & Good & Sunny & Creeping \\
\hline Sieboldi. . . . . . . . . . . . . Pink & $9 \mathrm{in.}$ & Aug., Sept. & Good & Sunny & Creeping \\
\hline Stoloniferum............. Pink & $6 \mathrm{in}$. & July, Aug. & Good & Sunny & Creeping \\
\hline Dasyphyllum............. White & $6 \mathrm{in}$. & July & Good & Sunny & Creeping \\
\hline Silene alpestris . . . . . . . . White & $6-8$ in. & July, Aug. & Sandy Joam & Shade & Creeping \\
\hline Statice latifolia........... Gray-blue & $10-18$ in. & July, Aug. & Good, sandy & Sun & Clumps \\
\hline Thymus serpyllum albus...... . White & 6-8 in. & June, July & Arid & Sun & Creeping \\
\hline Serpyllum citriodorus . . . . . . Lilac & $3-4$ in. & June-Aug. & Arid & Sun & Creeping \\
\hline Serpyllum coccineum......... Lilac & $3-4$ in. & June-Aug. & Arid & Sun & Creeping \\
\hline Serpyllum lanuginosus . ...... Pink & $3-4$ in. & June-Aug. & Arid & Sun & Creeping \\
\hline Vulgaris........... . Lilac & $3-4 \mathrm{in}$. & June, July & Arid & Sun & Creeping \\
\hline Tunica saxifraga........ & $10-12$ in. & July-Sept. & Good & Sun & Bushy, trailing \\
\hline Veronica incana............ & $10-12 \mathrm{in.}$ & May, June & Good (lime) & Sun & Erect \\
\hline Repens........... . Pale blue & $3-4$ in. & May & Moist or dry & Sun & Prostrate \\
\hline Rupestris................. Blue & $6-8 \mathrm{in}$. & May, June & Good & Sun & Trailing \\
\hline Rupestris rosea . . . . Rose & $6-8$ in. & May, June & Good & Sun & Trailing \\
\hline True Blue................ Blue & $6-12$ in. & May, June & Good & Sun & Erect \\
\hline Spicata................ Blue & $2-21 / 2 \mathrm{ft}$. & June, July & Good & Sun & Erect \\
\hline
\end{tabular}




\section{Rock-Plants and Perennials}

Delphinium, Blackmore and Langdon Hybrids. This strain consists of some of the finest Delphiniums. The plants arc of very vigorous habit, producing inmense spikes of flowers of the largest size, ranging in color from the palest blue and lavender to the deepest blue and purple. $50 \mathrm{cts}$. each; $\$ 5$ per doz.

English Hybrids. This strain consists of some of the linest Delphiniums seen anywhere. The plants are of very vigorous habit, producing immense spikes of flowers of the largest size, ranging in color from the palest blue and lavender to the deepest blue and purple. $50 \mathrm{cts}$. each; $\$ 5$ per doz.

Nudicaule. A dwarf variety, producing spikes of bright orangered tlowers in May and June. 35 cts. each; $\$ 3.50$ per doz.

DIANTHUS arenarius. This Pinh likes a sandy soil, and during May and June it bears masses of deeply fringed and fragrant white flowers.

Barbatus, Newport Pink. Sweet William. Produces great masses of salmon-rose flowers.

Cæsius. Very compact, making cushions of blue-gray foliage from which, in May, spring the sweetly scented, rosy pink flowers. 30 cts. each; $\$ 3$ per doz.

Deltoides. Maiden Pink. A beautiful trailing plant with narrow leaves, bearing a profusion of small pink flowers in June and July.

Deltoides albus. A white form of the above.

Deltoides, Brilliant. Vivid crimson flowers.

Deltoides rubrus. Brilliant, with vivid crinson flowers.

Dentosus. Large, fringed, white and pale pink flowers with showy eye.

Latifolius atrococcineus. Very showy flowers of rich fiery scarlet on long stems.

Plumarius. Very fragrant flowers on Iong stems. A continuous bloomer.

DICENTRA eximia. A fine, dwarf, fern-leaved plant with curving sprays of dark rose-pink flowers.

Formosa. Plumy Bleeding-Heart. A dwarf-growing BleedingHeart with finely cut foliage and showy racemes of pretty pink flowers throughout the season.

Spectabilis. The fine old-fashioned Bleeding-Heart which everybody likes. $50 \mathrm{cts}$., $75 \mathrm{cts}$., and $\$ 1$ each, according to size.

DICTAMNUS fraxinella alba. Gas Plant. A beautiful showy plant, growing about 2 to $21 / 2$ feet high, with white flowers in June and July. $40 \mathrm{cts}$. each; $\$ 4$ per doz.

Fraxinella rubra. Same as foregoing, with rose-pink flowers. 40 cts. each; $\$ 4$ per doz.

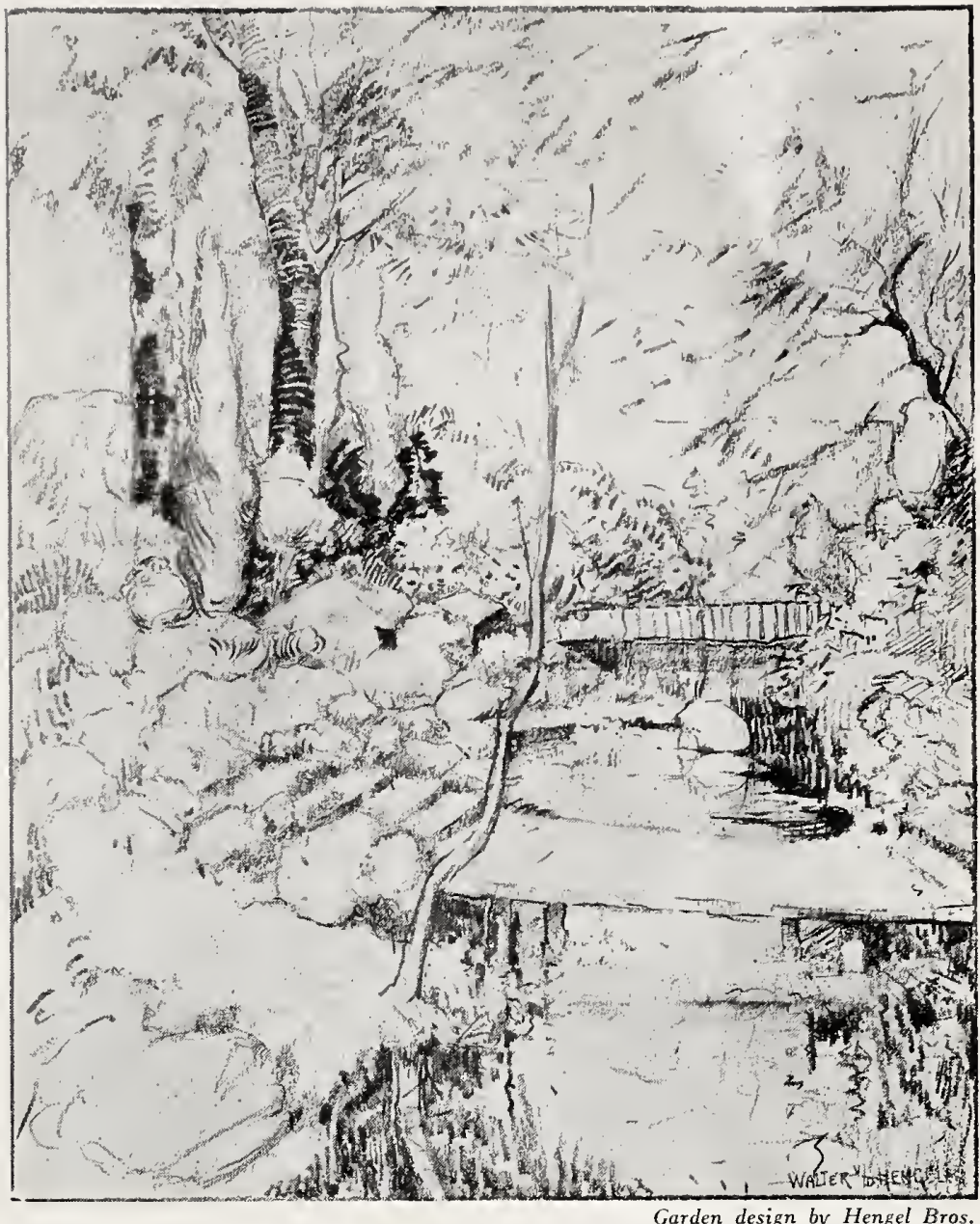

Garden design by Hengel Bros.

\section{Plants for Dry Walls}

$25 \mathrm{cts}$. each, $\$ 2.50$ per doz., unless otherwise noted in descriptive list

\begin{tabular}{|c|c|c|c|c|c|c|}
\hline Name & Color & Height & Season & Soil & Position & Habit \\
\hline Alyssum saxatile compactum. . & Yellow & $1 \mathrm{ft}$ & April, May & Good & Sun & Spreading \\
\hline Arabis alpina......... & White & $5-6$ in. & April, May & Good & Sun & Hanging \\
\hline Campanula rotundifolia. . & Blue & $1 \mathrm{ft}$. & June-Aug. & Good & Sun & Creeping; flowers erect \\
\hline Cerastium tomentosum.. & White & $6 \mathrm{in.}$ & May, June & Good (lime) & Sun & Hanging \\
\hline Daphne cneorum . . . . . . & Pink & $10-24$ in. & April, May & Leaf-mold, loam, peat & Base of wall & Dwarf, prostrate shrub \\
\hline Dianthus, in variety. & White, pink, red & 8 in. & May, June & Good (lime) & Sun & Hanging \\
\hline Gypsophila repens. & White & $6 \mathrm{in.}$ & June, July & Good (line) & Sun & Creeping \\
\hline Repens rosea ... & Pink & $6 \mathrm{in.}$ & June, July & Good (lime) & Sun & Creeping \\
\hline Heuchera sanguinea. & Crinison & 18 in. & May-Sept. & Good & Sun & Erect \\
\hline Iberi & White & $10 \mathrm{in.}$ & April, May & Good & Su & Spreading \\
\hline Iris cr & Lilac & 4-9 in. & May & Light, well-drained & Su & Dwarf \\
\hline Pumila... & Deep violet & $4-9 \mathrm{in}$. & May & Light, well-drained & Sun & Dwarf \\
\hline Linum $\mathbf{p}$ & Blue & $1 \mathrm{ft}$. & May-Aug. & Good (lime) & Sun & Erect \\
\hline Saponaria ocymoides. . & Pink & $6-9$ in. & June & Good & Sun & Creeping \\
\hline Sedum acre......... & Yeliow & $4-6$ in. & May, June & Good & Sun & Creeping \\
\hline Sarmentosum. . . . . . . & Yellow & $4-6$ in. & May, June & Good & Sun & Creeping \\
\hline Thymus serpyllum citriodorus. & Lilac & $3-4$ in. & June-Aug. & Good & Sun & Creeping \\
\hline Vulgaris................. & Lilac & $3-4 \mathrm{in}$. & June-Aug. & Good & Sun & Creeping \\
\hline Tunica saxifraga & Pale pink & & July-Sept. & Good & Sun & Hanging \\
\hline Veronica repens... & . Pale blue & $2-5 \mathrm{in}$ & May & Good & Sun & Creeping \\
\hline
\end{tabular}




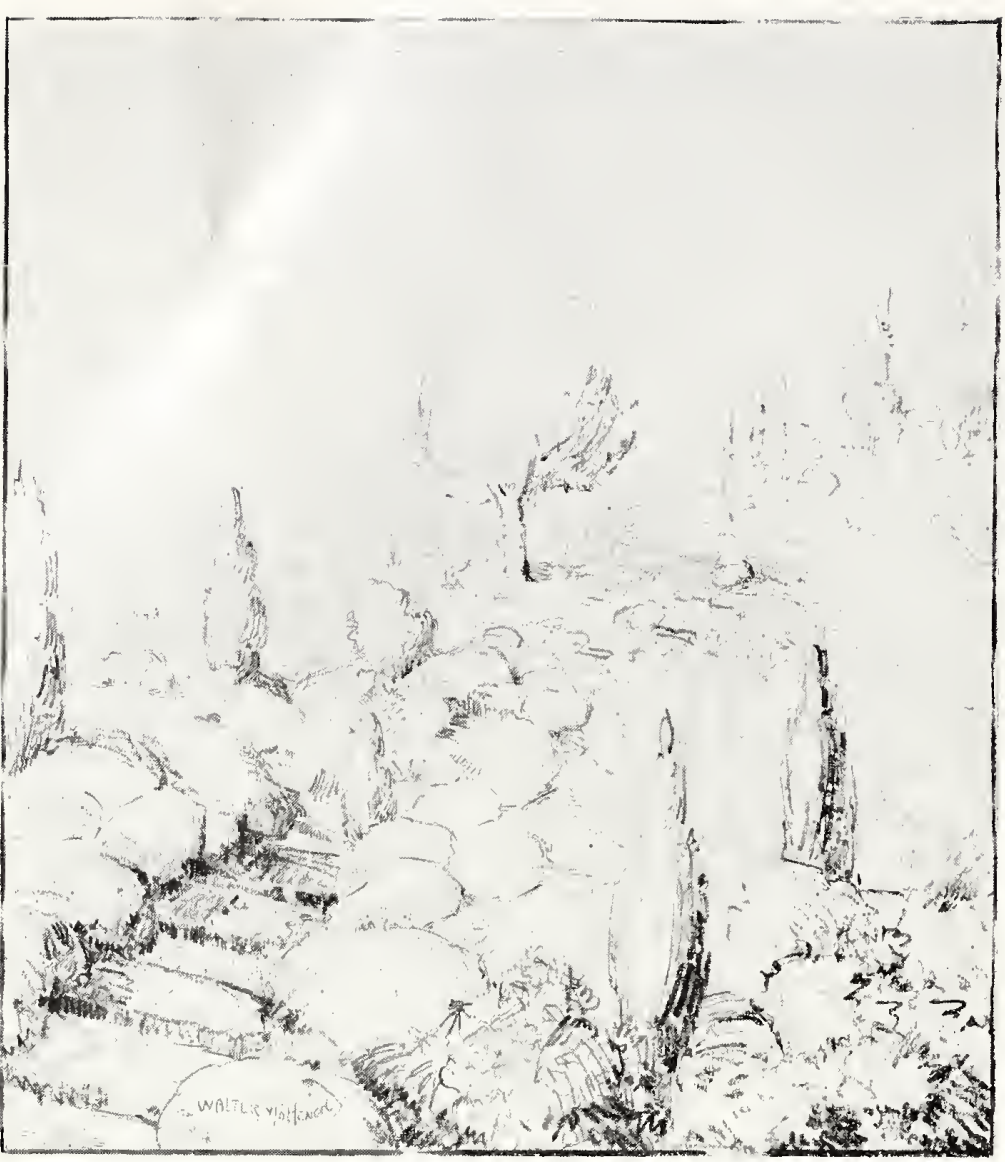

\section{Rock-Plants and Perennials}

DIGITALIS. Foxglove. One of the most attractive and statelygrowing, old-fashioned favorites, especially good in big masses.

Gloxiniæhora. In Purple, Pink, and White. Separate colors.

DORONICUM excelsum. Leopard's Banc. Bright yellow flowers on long stems early in the season.

EPIMEDIUM niveum. Low, shade-loving plants with extraordinarily beautiful foliage and small, very curious, white flowers.

ERIGERON speciosus. Midsummer Daiss, An attractive perennial with large, clear, pale mauve flowers, with bright golden centers. $18 \mathrm{in.} \mathrm{Excellent} \mathrm{for} \mathrm{cutting.}$

ERINUS alpinus. Pretty rosettes of foliage and racemes of rosy purple flowers. $30 \mathrm{cts}$. each; $\$ 3$ per doz.

ERYSIMUM, Golden Gem. Covered with golden yellow flowers in early spring.

Linifolium. The mauve Alpine Wallflowers. A Iovely rcckplant, producing masses of clear mauve flowers in May and June. $40 \mathrm{cts}$. each; $\$ 4$ per doz.

Pulchellum. A compact Wallflower, growing only 6 inches high, bearing pale yellow flowers in profusion early in spring. 35 cts. each; $\$ 3.50$ per doz.

EUPATORIUM coelestinum. A fine plant for cutting with pretty bright blue ageratum-like flowers.

Purpureum. Interesting, late-blooming plants with broad heads of lovely blue-purple flowers.

EUPHORBIA polychroma. A beautiful and interesting plant, covered in May and June with yellow flowers.

FUNKIA cærulea. Broad green leaves and blue flowers.

Picta media. Interesting decorative foliage. Rare variety.

Subcordata. Broad, heart-shaped foliage, with sprays of lavender, lily-like flowers.

Variegata. Variegated Plantain Lily. Blue flowers. Excellent for edging.

GAILLARDIA grandiflora. Blanket Flower. The most dependable cut-flower of all. Its crimson blooms bordered yellow, are borne constantly from June till October.

\section{Bog Plants and Plants for Moist Places}

\begin{tabular}{|c|c|c|c|c|c|c|c|c|}
\hline Name & Color & Height & Season & Soil & Position & Habit & Each & Doz. \\
\hline Astilbe, in variety. . & Mixed & $2-4 \mathrm{ft}$. & July-Sept. & Rich & Shade & Clumps & $\$ 075$ & \\
\hline Caltha palustris........ & Yellow & $1-2 \mathrm{ft}$. & April, May & Rich & Partial shade & Clumps & 25 & $\$ 250$ \\
\hline Eupatorium purpureum. & Soft purple & $5-7 \mathrm{ft}$. & July-Sept. & Rich & Partial shade & Clumps & 25 & 250 \\
\hline Hemerocallis, in variety. & Yellow, orange & $3-4$ it. & June & Rich & Partial shade & Clumps & 25 & 250 \\
\hline Hibiscus moscheutos. . & White and pink & $3-5 \mathrm{ft}$. & July, Aug. & Rich & Partial shade & Clumps & 25 & 250 \\
\hline $\begin{array}{l}\text { Iris kaempferi } \ldots . . . \\
\quad \text { Pseudacorus...... }\end{array}$ & $\begin{array}{l}\text { Sce special list } \\
\text { Yellow }\end{array}$ & $\begin{array}{l}2-4 \mathrm{ft} \\
2-3 \mathrm{ft}\end{array}$ & $\begin{array}{l}\text { June, July } \\
\text { May, June }\end{array}$ & $\begin{array}{l}\text { Rich, peat } \\
\text { Rich }\end{array}$ & $\begin{array}{l}\text { Sun } \\
\text { Marginal-sun }\end{array}$ & $\begin{array}{l}\text { Clumps } \\
\text { Clumps }\end{array}$ & 25 & 250 \\
\hline Lobelia cardinalis. & Crimson & $2-4 \mathrm{ft}$. & July-Sept. & Rich & Sun or shade & Clumps & 25 & 250 \\
\hline Mimulus cardinalis. & Crimson & $12-18 \mathrm{in.}$ & July & Rich & Sun or shade & Clumps & 30 & 300 \\
\hline Myosotis palustris... & Blue & $8 \mathrm{in.}$ & May-Sept. & Rich & Sun or shade & Clumps & 25 & 250 \\
\hline $\begin{array}{l}\text { Primula beesiana. } \\
\text { Cortusoides }\end{array}$ & Purple & $2 \mathrm{ft}$ & May-July & Rich & $\begin{array}{l}\text { Partial shade } \\
\text { Sun }\end{array}$ & $\begin{array}{l}\text { Clumps } \\
\text { Clunps }\end{array}$ & $\begin{array}{l}75 \\
50\end{array}$ & $\begin{array}{l}900 \\
500\end{array}$ \\
\hline & In variety & 12-18 in. & May, June & $\begin{array}{l}\text { Rich, sandy } \\
\text { Rich, sandy }\end{array}$ & Shade & & 35 & 350 \\
\hline Littoniana. & Lilac and purple & $2 \mathrm{ft}$. & May, June & Rich, sandy loam & Partial shade & Climps & 75 & \\
\hline
\end{tabular}

\section{A Few Plants for Poor Soil}

25 cts. each, $\$ 2.50$ per doz.

\begin{tabular}{|c|c|c|c|c|c|}
\hline Name & Height & Season & Soil & Position & Habit \\
\hline Alyssum saxatile............. Yellow & $1 \mathrm{ft}$. & April-June & Sandy & Sun & Spreading \\
\hline Ayuilegia canadensis........... Yellow and scarlet & $1-2 \mathrm{ft}$. & April-June & Sandy & Sun or shade & Cluinps \\
\hline Arabis alpina. ............. White & 6 in. & April, May & Sandy & Sun & Spreading \\
\hline Cerastium tomentosum........ White & $3-6$ in. & June & Sandy & Sun & Trailing \\
\hline 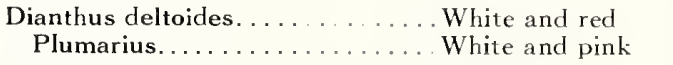 & $\begin{array}{l}6-9 \text { in. } \\
6-12 \text { in. }\end{array}$ & $\begin{array}{l}\text { May, June } \\
\text { May, June }\end{array}$ & $\begin{array}{l}\text { Sandy } \\
\text { Sandy }\end{array}$ & $\begin{array}{l}\text { Sun } \\
\text { Sun }\end{array}$ & $\begin{array}{l}\text { Dwarf } \\
\text { Truiling }\end{array}$ \\
\hline Iberis sempervirens. ........... Varied & $9-15 \mathrm{in.}$ & May, June & Sandy & Sun & Dwarf \\
\hline Phlox subulata.............. Varied & $4-6 \mathrm{in.}$ & April, May & Sandy & Sun & Creeping \\
\hline $\begin{array}{l}\text { Sedum acre................ } \\
\quad \text { Stoloniferum. . . Y ellow } \\
\end{array}$ & $\begin{array}{l}3-4 \text { in. } \\
3-4 \text { in. }\end{array}$ & $\begin{array}{l}\text { May } \\
\text { July, Aug. }\end{array}$ & $\begin{array}{l}\text { Dry, sandy } \\
\text { Dry, sandy }\end{array}$ & $\begin{array}{l}\text { Sun } \\
\text { Sun }\end{array}$ & $\begin{array}{l}\text { Creeping } \\
\text { Creeping }\end{array}$ \\
\hline Veronica rupestris............ Blue & $6-8 \mathrm{in.}$ & May, June & Sandy & Sun & Creeping \\
\hline
\end{tabular}




\section{Rock-Plants and Perennials}

GEUM, Lady Stratheden. Ercct plants, with Iarge, bright ycllow flowers, like single roses.

Mrs. Bradshaw. Samc as preceding, with double rich scarlet flowers. $18 \mathrm{in}$. Both Geums are very fine for cutting. $30 \mathrm{cts}$. cach; $\$ 3$ per doz.

GYPSOPHILA repens. A pretty trailing plant with clouds of small whitc flowers in June and July.

Repens rosea. A charming pink-flowered form.

HEMEROCALLIS flava. The tall fragrant lemon Lily. Very handsome for cutting and garden decoration.

Fulva. Tawn Day Lily. Orange-yellow with crimson markings. Very permanent.

HELIANTHEMUM chamæcistus macranthum. Large, creamy white flowers. 35 cts. each; $\$ 3.50$ per doz.

Fireball. Brilliant scarlet. $35 \mathrm{cts}$. each; $\$ 3.50$ per doz.

Mrs. Earle. Double; scarlet. 35 cts. each; $\$ 3.50$ per doz.

Praecox. Soft yellow flowers with silvery foliage. $35 \mathrm{cts}$. each; $\$ 3.50$ per doz.

Rhodanthum carneum. Very large, clear pink flowers. Silvery foliage. 35 cts. each; $\$ 3.50$ per doz.

Vulgare mutabile. Tiny, wiry shrubs covered with charming, satiny flowers of white, pink, and cream.

Choice Mixed Varieties. 35 cts. each; $\$ 3.50$ per doz.

HEUCHERA micrantha hybrida. A wonderful hybrid strain of Coral Bells, producing very freely large panicles of flowers ranging in color from the palest pink to vivid crimson.

Sanguinea. Coral Bells. Beautiful plant with heart-shaped foliage and bright crimson flowers on slender stems. $35 \mathrm{cts}$. each; $\$ 3.50$ per doz.

HIBISCUS moscheutos. Broad, swamp plants with giant white and pink blooms. Very striking.

HIERACIUM villosum. Soft, downy, silvery leaves and goIden yellow flowers in June and July. Very striking. $40 \mathrm{cts}$. each; $\$ 4$ per doz.

HOLLYHOCKS. Double Newport Pink.

HYPERICUM polyphyllum. A charming, trailing plant with grayish foliage and producing large golden yellow flowers. 50 cts. each; $\$ 5$ per doz.

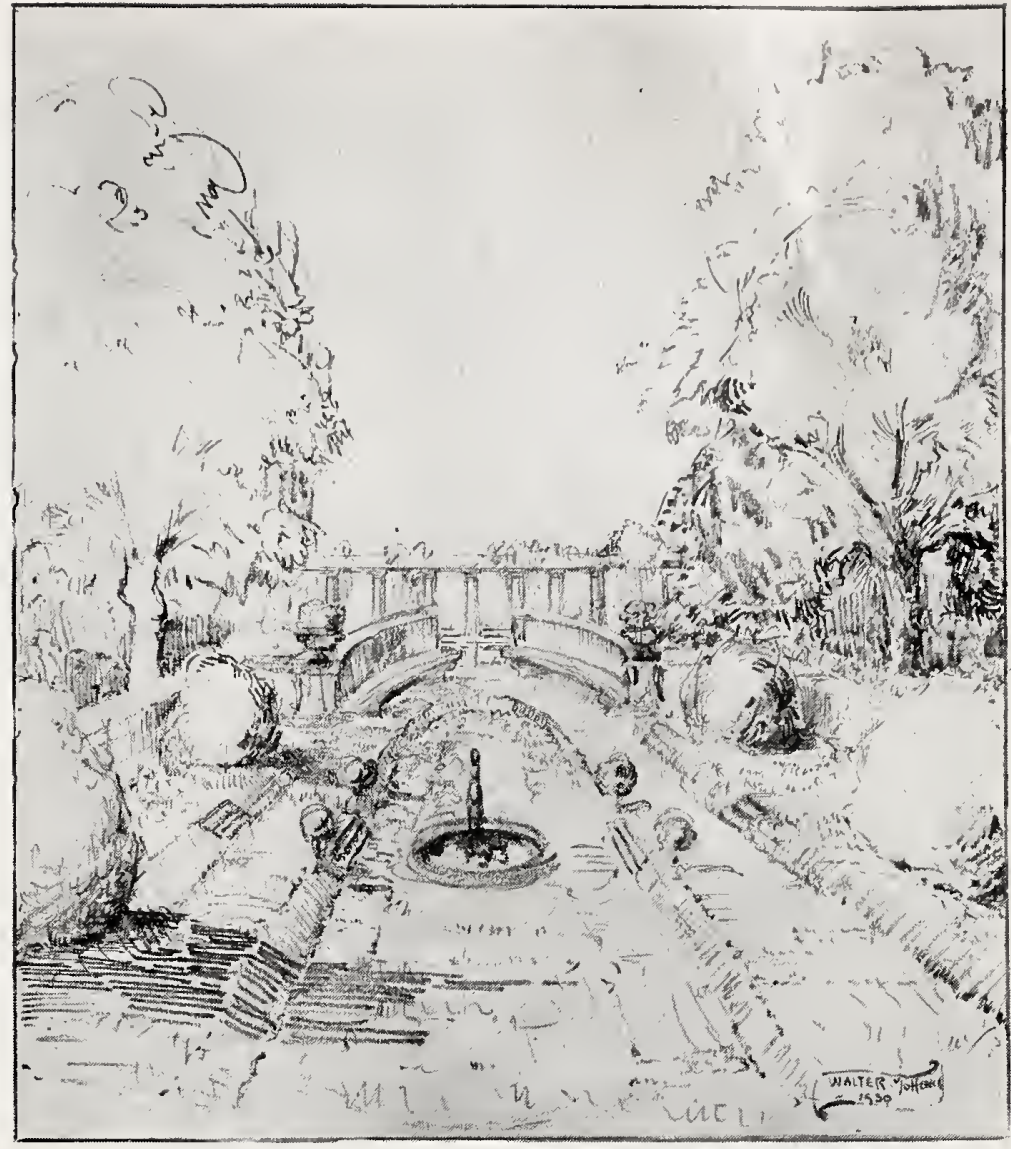

Garden design by Hengel Bros.

\section{Plants Which Will Flower in the Shade}

\begin{tabular}{|c|c|c|}
\hline $\begin{array}{l}\text { Name } \\
\text { Ajuga reptans... . . }\end{array}$ & $\begin{array}{l}\text { Color } \\
\text { Blue }\end{array}$ & $\begin{array}{l}\text { Height } \\
3-4 \text { int. }\end{array}$ \\
\hline Asperula odorata . . . . . . & White & $6-8$ in. \\
\hline Dicentra formosa...... & Pink & $1 \mathrm{ft}$. \\
\hline Epimedium niveun $\ldots . .$. & White & $6-8$ in. \\
\hline Funkia subcordata . . . . . & Lavender & $12-18$ in \\
\hline Pachysandra terminalis... & Evergreen & $6-8 \mathrm{in}$. \\
\hline Primula veris . . . . . . & Yellow & $6 \mathrm{in}$. \\
\hline Vinca minor. . . . . & Blue & $8-10$ il \\
\hline
\end{tabular}

\section{Small Bulbs for Rock-Garden}

\section{Prices on application}

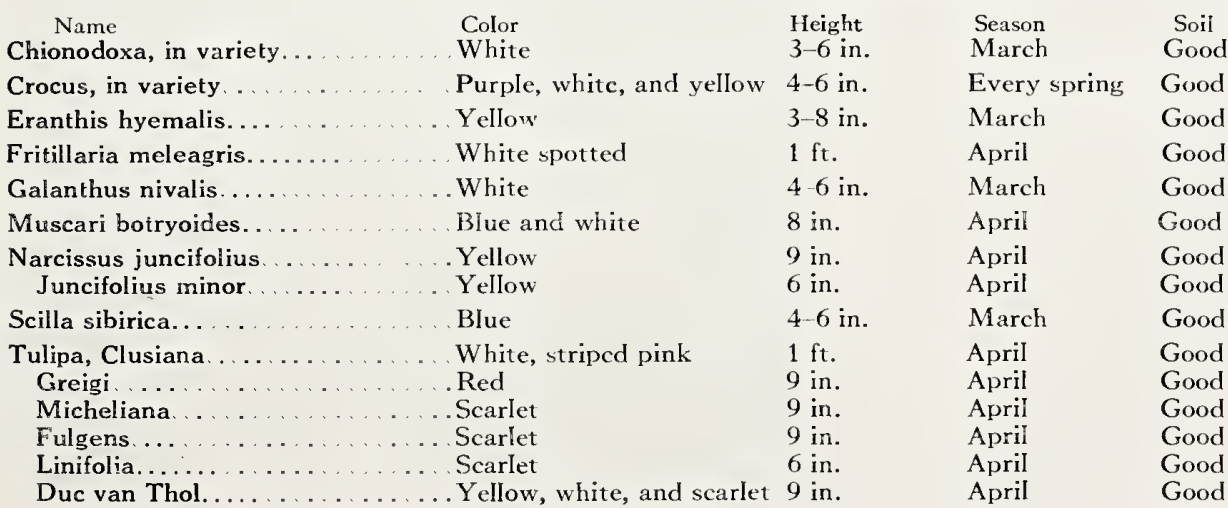

Duc van Thol............... Yellow, white, and scarlet 9 in.
Position

Sun or shade

Partial or full shade

Partial shade

Shade

Sun or shade

Sun or shade

Shade or partial shade

Sun or shade
Habit

Creeping

Clumps

Clumps

Clumps

Clumps

Spreading

Clumps

Trailing

$\begin{array}{ll}\text { Position } & \text { Habit } \\ \text { Sun or part shade } & \text { Clumps } \\ \text { Sun or shade } & \text { Clumps } \\ \text { Sun or part shadc } & \text { Clumps } \\ \text { Sun or part shade } & \text { Clumps } \\ \text { Sun or part shade } & \text { Clumps } \\ \text { Sun or part shade } & \text { Clumps } \\ \text { Sun or part shade } & \text { Species } \\ \text { Sun or part shade } & \text { Species } \\ \text { Sun or part shade } & \text { Clumps } \\ \text { Sun or part shade } & \text { Species } \\ \text { Sun or part shade } & \text { Species } \\ \text { Sun or part shade } & \text { Specics } \\ \text { Sun or part shadc } & \text { Species } \\ \text { Sun or part shade } & \text { Species } \\ \text { Sun or part shade } & \end{array}$




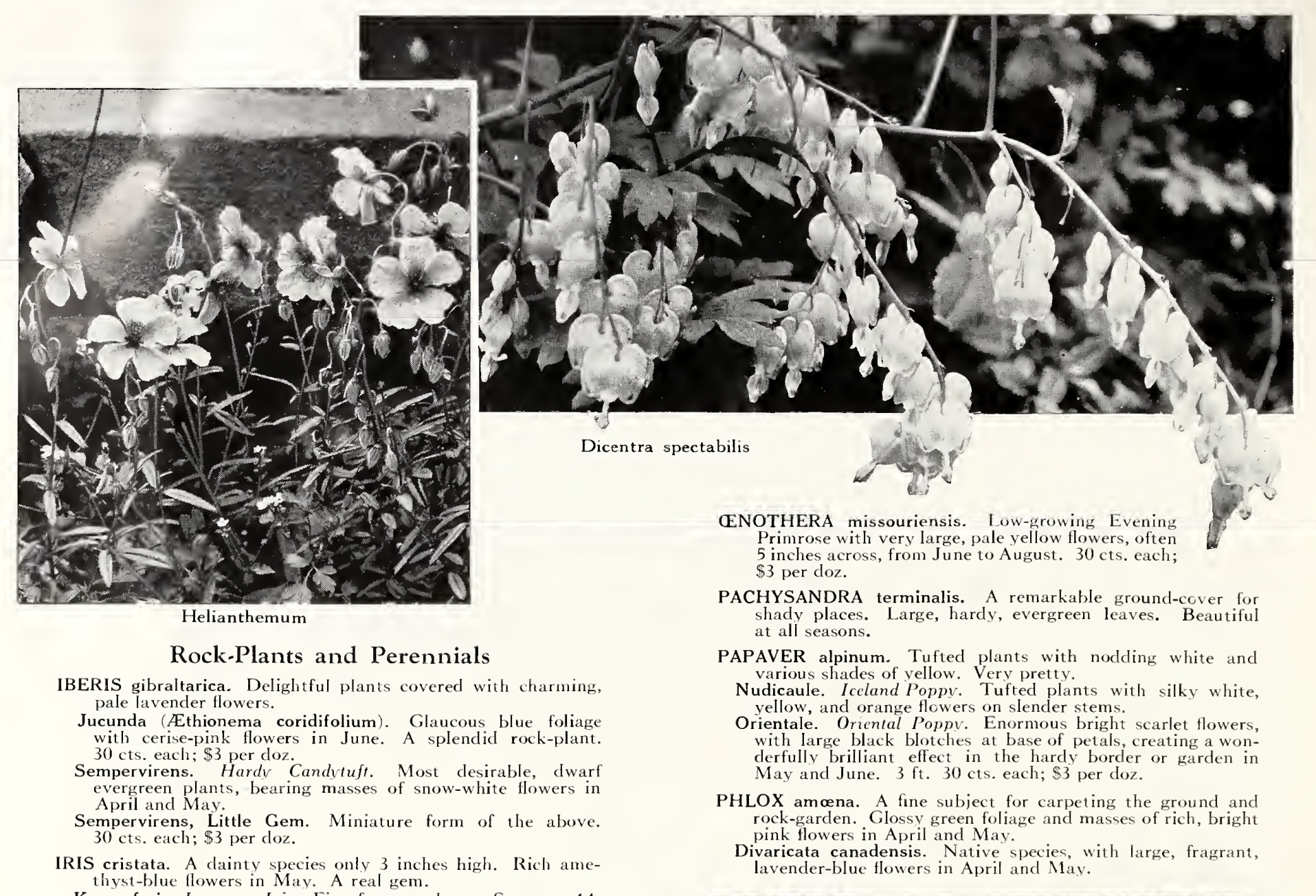

Kaempferi. Japanese Iris. Fine for wet places. See page 14.

Pseudacorus. Tall, rush-like, moisture-loving plants with brilliant yellow flowers.
Pumila. Another fine dwarf Iris 4 inches high, with larger flowers than the foregoing. $30 \mathrm{cts}$. each; $\$ 3$ per doz.

Pumila, The Bride. A large-flowered, pure white form.

Sibirica orientalis. Rush-like plant with erect stems, bearing large flowers like blue butterflies.

LEONTOPODIUM alpinum. Edelweiss. The well-known alpine with pretty white leaves and small vellow flowers, surrounded by star-like heads of leaves clothed with a dense, white woolly substance. June to August. 35 cts. each; $\$ 3.50$ per doz.

LINUM perenne. Very attractive plant and continuous bloomer. Lovely pale blue flowers on slender, graceful stems.

LOBELIA cardinalis. Cardinal Flower. A shade- and moistureloving plant with blazing scarlet-crimson blooms. Most effective.

LUPINUS polyphyllus. Clear blue. $35 \mathrm{cts}$. each; $\$ 3.50$ per doz. Polyphyllus albus. Pure white. $35 \mathrm{cts}$. each; $\$ 3.50$ per doz. Polyphyllus roseus. A fine variety with rose-shaded flowers. 35 cts. each; $\$ 3.50$ per doz.

LYCHNIS alpina. Compact cushions of rich green leaves, studded in April and May with heads of pink flowers.

Arkwrighti. Large, vivid pink flowers changing to orange. Very showy.

MERTENSIA virginica. An early spring-flowering native plant, with drooping panicles of light blue flowers fading to clear pink.

MIMULUS cardinalis. Large, curiously shaped, scarlet flowers profusely produced. A swamp plant. $30 \mathrm{cts}$. each; $\$ 3$ per doz.

MYOSOTIS palustris semperflorens. Forget-me-not. Charming sprays of pure light blue flowers of great beauty.

NEPETA mussini. Catmint. An excellent rock-plant of compact habit, with silvery leaves, producing masses of lavender flowers in June.

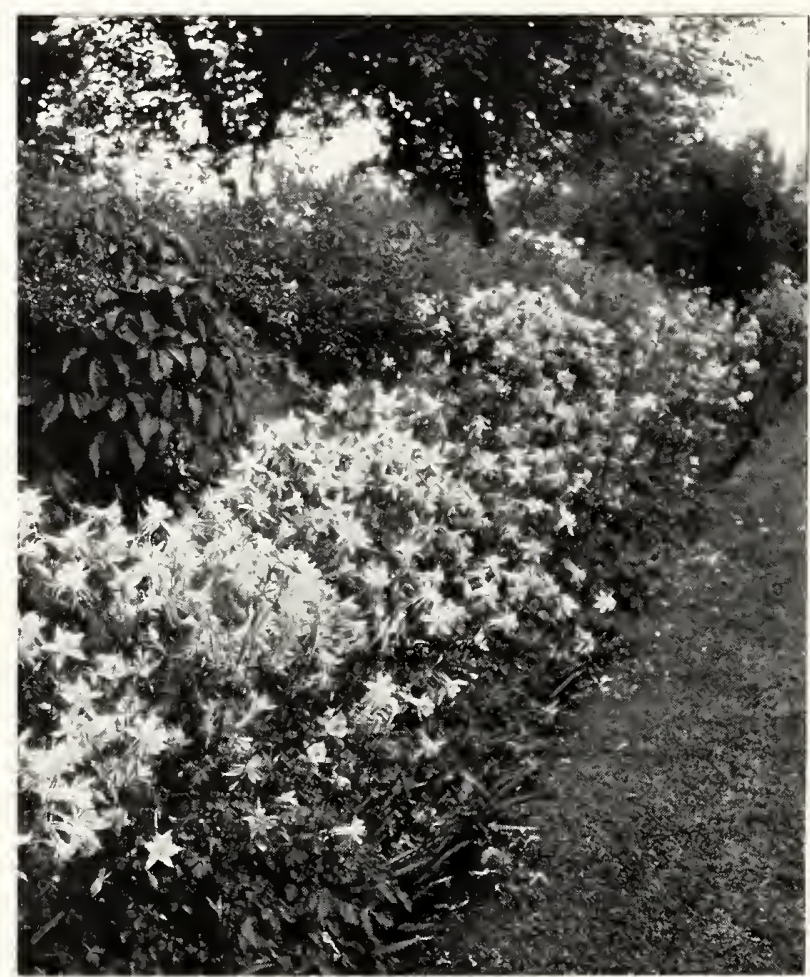

Aquilegia border 


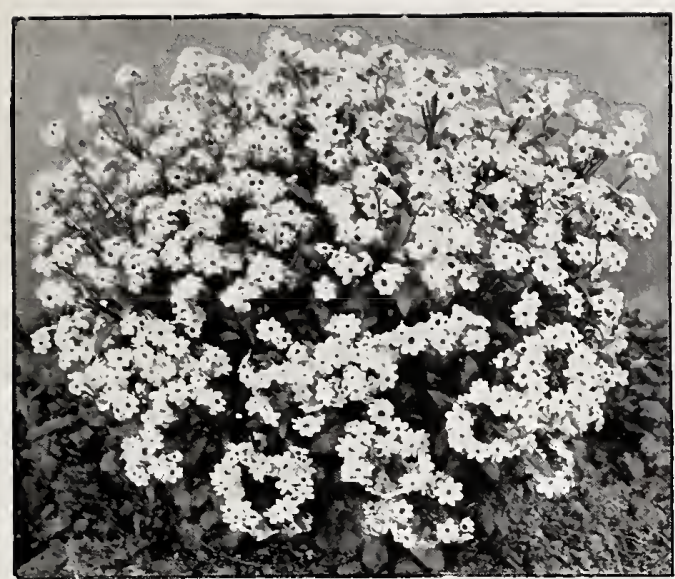

Myosotis (Forget-me-not)

Rock-Plants and Perennials

Phlox subulata alba. A pure white form.

Subulata, G. F. Wilson. Brilliant shell-pink.

Subulata lilacina. Light Iilac.

Subulata rosea. An early spring-flowering type, with mosslike, evergreen foliage, hidden under masses of rose-pink flowers in April and May.

Subulata, Vivid. This is the brightest of the Subulata typea deep fiery rose.

PHYSALIS francheti. Chinese Lantern. An ornamental plant growing about 2 feet high, producing bright orange-scarlet fruits which are very decorative and are greatiy used in winter in a dried state. $30 \mathrm{cts}$. each; $\$ 3$ per doz.

PLATYCODON grandiflorum. Balloon Flower. Throws up spikes 18 inches to 2 feet, with large, blue, bell-shaped flowers from June to October. Very showy.

Grandiflorum album. White flowers.

PLUMBAGO Iarpentæ (Ceratostigma plumbaginoides). One of the few late-flowering rock-plants, of dwarf, spreading habit, covered with very fine deep blue flowers. August to October.

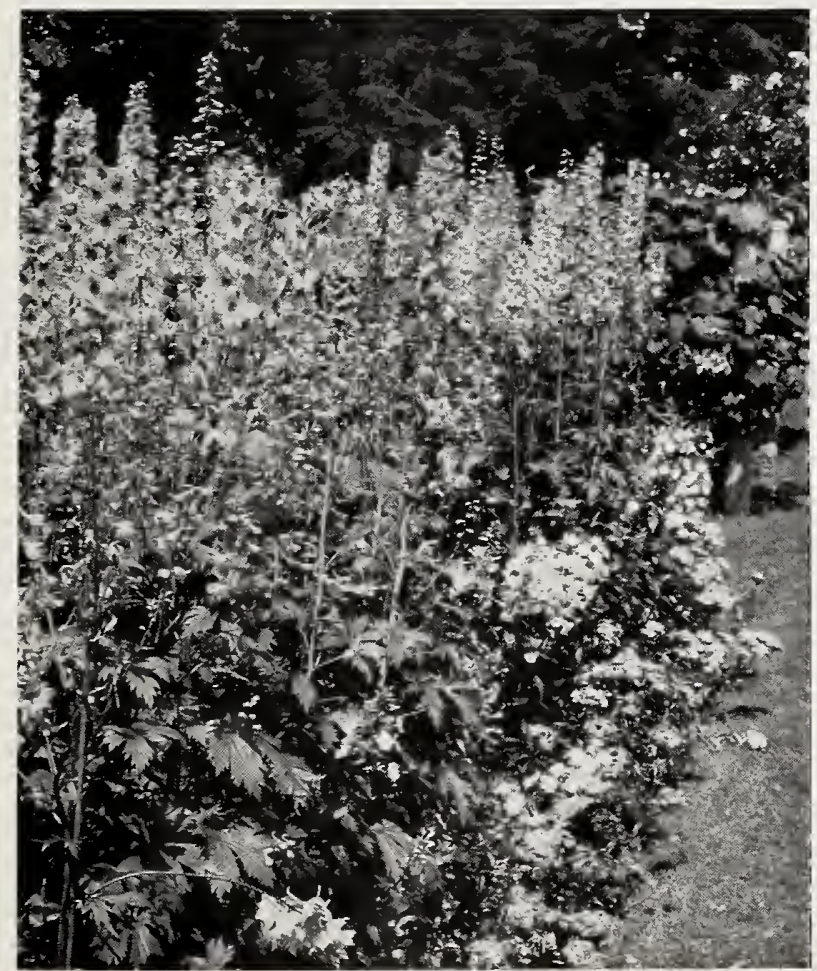

Hybrid Delphiniums

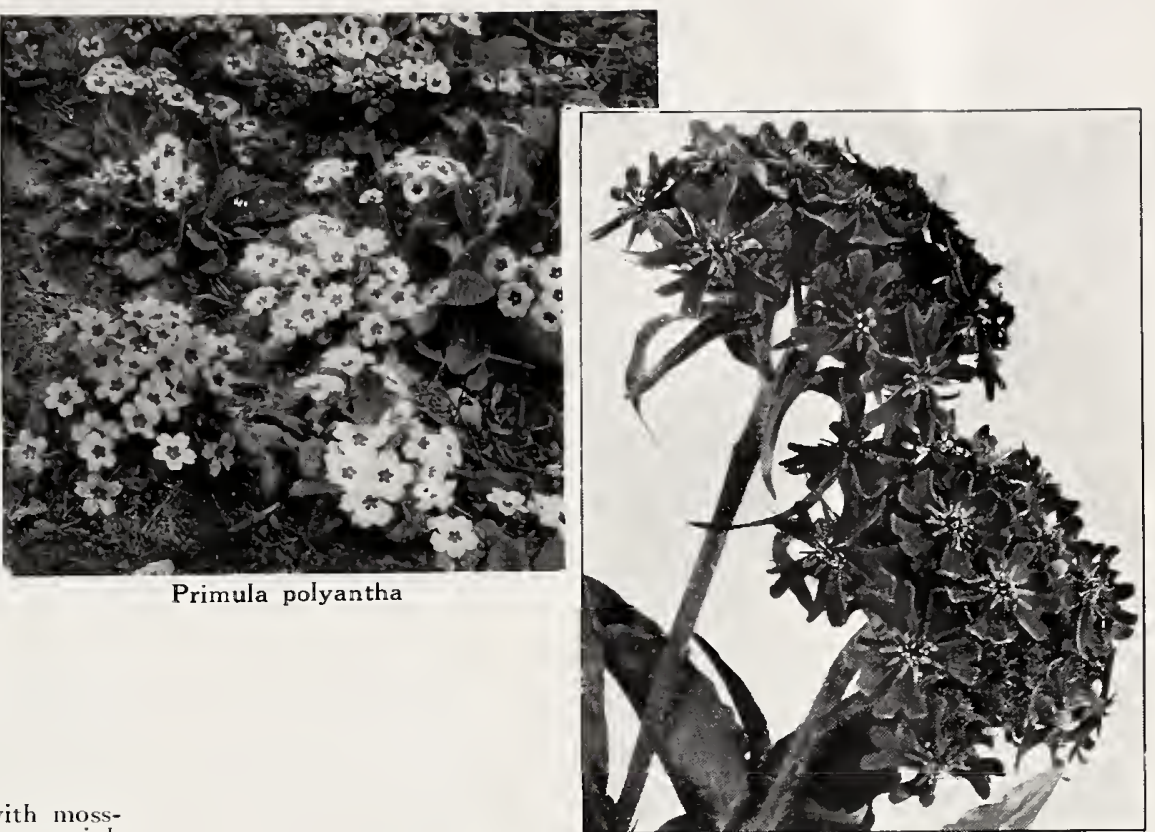

Lychnis alpina

POLEMONIUM reptans. A very showy little plant with blue flowers in April and May. 30 cts. each; \$3 per doz.

PRIMULA. Hardy Primrose. No class of plants provides us with lovelier subjects for the rock-garden than the Primrose family. The varieties offered below are all perfectly hardy if given a covering through the winter.

Auricula. A very interesting little plant forming rosettes of thick, leathery leaves, often heavily powdered with a mealy substance called farina, and throwing up flower-spikes in early spring of a great variety of colors and very fragrant. 40 cts. each; \$4 per doz.

Auricula alpina. This variety has not as wide a range of coloring as the foregoing, but is otherwise every bit as lovely. $40 \mathrm{cts}$. each; $\$ 4$ per doz.

Beesiana. A distinct, tall variety with whorls of rich velvety purple flowers. 75 cts. each; $\$ 9$ per doz.

Cortusoides. Clusters of slender stems with bright rosy pink flowers. $50 \mathrm{cts}$. each; $\$ 5$ per doz.

Denticulata cachemiriana. A beautifuI, strong-growing variety with large, globular heads of flowers, ranging from pure white through mauve to purple and violet. 50 cts. each; \$5 per doz.

Elatior. Flowers very early in spring and has a great variety of coloring. $30 \mathrm{cts}$. each; \$3 per doz.

Elatior, Invincible. A strain of the foregoing, of more vigorous habit, and producing larger flowers. $35 \mathrm{cts}$. each; $\$ 3.50$ per doz.

Frondosa. A charming spring-blooming variety with silvery foliage and spikes of rosy Iilac flowers. 50 cts. each; \$5 per doz.

Japonica. Erect stenis with several whorls of white, pink, rose, and lilac flowers. $35 \mathrm{cts}$. each; $\$ 3.50$ per doz.

Littoniana. Rare variety having long stems, with crimson buds and mauve flowers. Very choice. $75 \mathrm{cts}$. each; $\$ 9$ per doz.

Polyantha. Charming rosettes of foliage with clusters of manycolored flowers. Beautiful for bedding, edging, and rockgardens.

Veris. Cowslip. This is one of the best-known Primroses, producing flowers of a great many colors in early spring. $30 \mathrm{cts}$. each; \$3 per doz.

Veris gigantea. Giant Cowslip. A greatly improved, largeflowering strain of the foregoing. $35 \mathrm{cts}$. each; $\$ 3.50$ per doz.

Vulgaris. English Primrose. Very fragrant, canary-yellow flowers.

PYRETHRUM hybridum. Painted Daisy. The Pyrethrums should be included in every planting where perennial plants are used. They are extremely hardy, with pretty fern-like foliage, and bear their bright, many-colored, daisy-like flowers on long, slender stems 2 feet high in May and June. Very valuable for cut-flowers.

RANUNCULUS acris flore-pleno. A pretty, double-flowering, golden yellow Buttercup. Blooms in May and June. 
SANTOLINA chamæeyparissus incana. Dwarf-growing, aromatic plant, with fine silvery foliage. $30 \mathrm{cts}$. each; $\$ 3$ per doz.

SAPONARIA ocymoides. An excellent rock-plant with rosepink flowers in spring.

SCABIOSA caucasica. A fine and useful perennial to grow in the border or garden. The delicate lavender blooms are borne from June till September. 30 cts. each; $\$ 3$ per doz.

SEDUM acre. Moss-like, green foliage and yellow flowers in Album. Small, succulent leaves which turn reddish bronze in laII. White flowers in June and July.

Dasyphyllum. Dwarf, compact variety. White flowers.

Hispanicum. A small plant forming spreading tufts of gray foliage turning bronze in fall.

Kamtschaticum. Orange-yellow flowers in July and August. Prostrate green foliage, turning golden in autumn.

Lydium. Makes carpets of bright green foliage, turning reddish bronze during summer.

Obtusatum. Sma!I, round, emerald-green foliage, turning red in summer. Golden yellow flowers in $J_{\text {une. }}$

Sarmentosum. Trailing variety with bright yellow flowers.

Sexangulare. Dark green foliage and yellow flowers in June and July.

Sieboldi. A very pretty Sedum with round, succulent, glaucous leaves and clusters of bright pink flowers in August and September.

Stoloniferum. Fine trailing variety with pink flowers in June and July.

SILENE alpestris. A delightful little plant, producing, in May and June, a great number of shining, white flowers with fringed petals. Succeeds best in shady position in the rockgarden. 30 cts. each; $\$ 3$ per doz.

STATICE latifolia. Handsome plant with shiny, leathery leaves and immense panicles of minute purplish blue flowers in July and August.

STOKESIA cyanea. Cornflower Aster. A very attractive plant, growing 18 to 24 inches high, with glossy green foliage and a profusion of handsome lavender-blue, aster-like flowers, measuring fully 4 to 5 inches across, from July till October.
THALICTRUM dipterocarpum. A beautiful, strong-growing plant, producing graceful sprays of dainty flowers of a lovely shade of violet-mauve. Fine for cutting. $30 \mathrm{cts}$. each; $\$ 3$ per doz.

THYMUS serpyllum albus. White flowers.

Serpyllum coccineum. Brilliant crimson-scarlet flowers

Serpyllum citriodorus. The well-known Lemon 'Thyme.

Serpyllum lanuginosus. Woolly foliage; bright pink flowers.

Vulgaris. An aromatic, low shrub with small Iilac flowers.

TRITOMA pfitzeri. Red-bot Poker. This very striking and beautiful late-flowering plant makes tufts of grass-like foliage and throws up spikes 2 to 3 feet high, with heads of bloom of a rich orange-scarlet through September and October. They produce a wonderful effect in the hardy border. The roots should have a good protection through the winter or stored away in sand in a cool cellar. $30 \mathrm{cts}$. each; $\$ 3$ per doz.

TUNICA saxifraga. Makes tufts of grass-like foliage and masses of small, rose-pink flcwers from July till September.

VERONICA incana. A very pretty plant with silvery foliage, producing slender spikes of deep blue flowers in May and June.

Longifolia subsessilis. Speedwell. A very handsome plant, throwing up spikes 2 feet long, completely studded with beautiful blue flowers through July and September. 30 cts. each; $\$ 3$ per doz.

Repens. Carpets of evergreen foliage, covered in spring with pale blue flowers.

Rupestris. A trailing variety, forming a thick mass of deep green foliage, hidden in May and June under a cloud of bright blue flowers.

Rupestris rosea. Like foregoing, with mauve-pink flowers. Very showy. $35 \mathrm{cts}$. each; $\$ 3.50$ per doz.

Spicata. Pretty plants covered from June until frost with spikes of violet-blue flowers. 18 in.

True Blue. Fine variety covered with small spikes of intense blue flowers in June and July. 35 cts. each; $\$ 3.50$ per doz.

VIOLA cornuta, Jersey Gem. The finest and most prolific bloomer of the Cornuta type. Flowers a pure rich violet, slightly perfumed. $35 \mathrm{cts}$, each; $\$ 3.50$ per doz.

Cornuta, Blue Perfection.

Cornuta, White Perfection

Cornuta, Yellow Perfection.

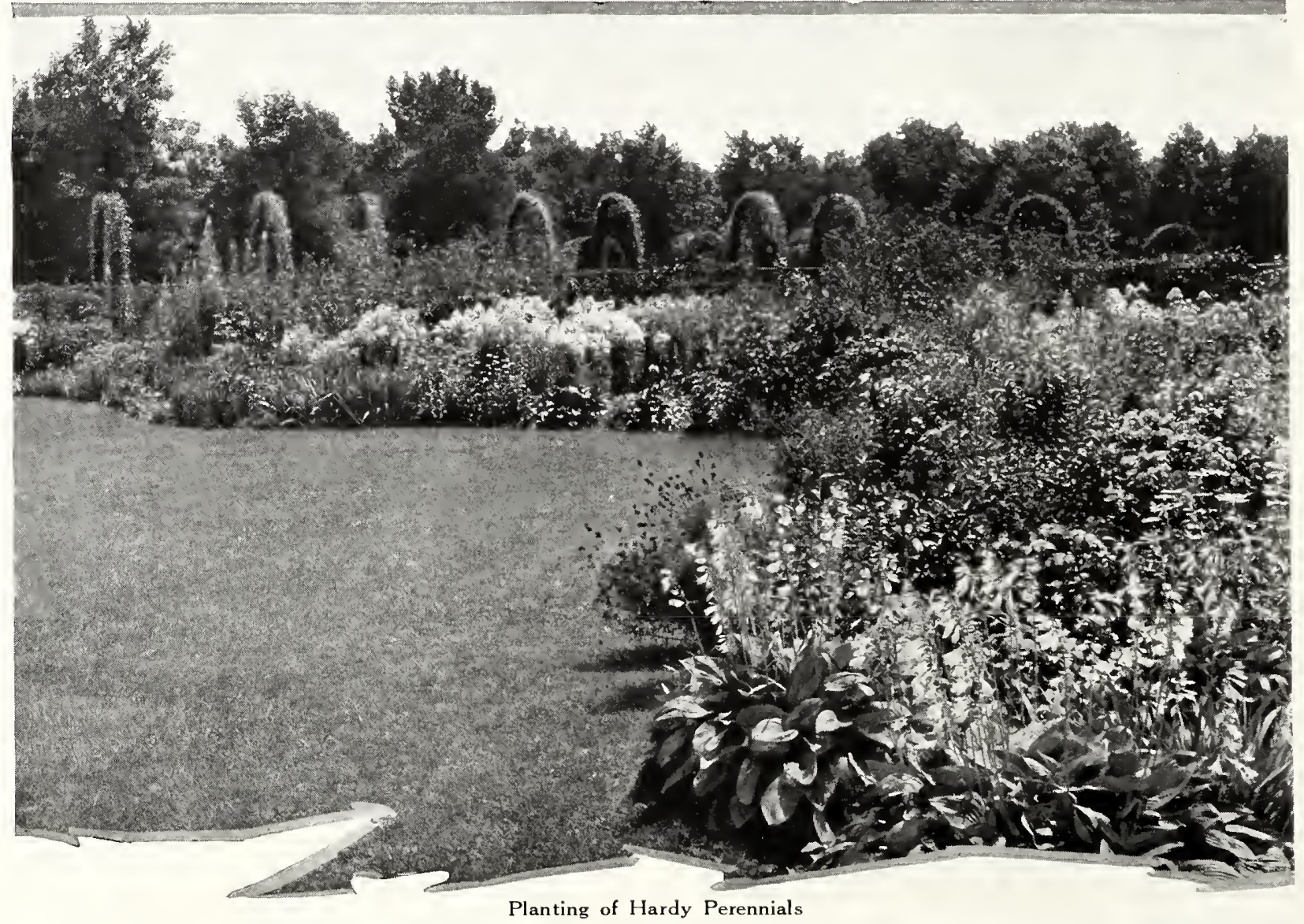




\section{Hardy Phlox}

No garden or border is complete without some clumps of this beautiful and showy perennial plant with its large range and richness of color. The list we offer below is made up of only the best and newer varicties.

B. Comte. A beautiful, rich shade of purple. $25 \mathrm{cts}$. $\mathrm{cach}_{1} ; \$ 2.50$ per doz.

Firebrand. Bright vermilion-scarlet. $30 \mathrm{cts}$. each; $\$ 3$ per doz.

Miss Lingard. The best pure white Phlox grown. Begins to bloom early in June and again in late autumn. $25 \mathrm{cts}$. each; $\$ 2.50$ per doz.

Mrs. Ethel Priehard. A beautiful light lilac. $40 \mathrm{cts}$. each; $\$ 4$ per doz.

Mrs. Milly van Hoboken. Soft pink without eye. A Iovely new variety. $40 \mathrm{cts}$. each; $\$ 4$ per doz.
Mrs. Rutgers. New. A finc liglit lilac-pink with durker center. $40 \mathrm{cts}$. each; $\$ 4$ per doz.

Mrs. Scholton. New. Makes cnormous pyramida! spikes of a beautiful dark salmon-pink color. $40 \mathrm{cts}$. each; $\$ 4$ per doz.

Prof. Virchow. Bright carmine, overlaicl with orange-scarlet. 25 cts. each; $\$ 2.50$ per doz.

Speeial French. Beautiful blush-pink with salmon eye. Enormous flowers. $35 \mathrm{cts}$. each; $\$ 3.50$ per doz.

Thor. Rich salmon-pink with deep crimson eye. $25 \mathrm{cts}$. each; $\$ 2.50$ per doz.

\section{Peonies}

The present-day Peony is unsurpassed by any other garden flower for the glorious showing it produces during the month of June, rivaling even the rose in that respect. The most effective way to use these plants is in beds or borders by themselves, where they can stay undisturbed for several years. As the existing number of Peonies is very largc, we have confined our list to the following varieties, including only the best. The roots we offer are strong, and have 3 to 5 eyes.

Albatre. Very large, compact, globular, rose type. Milk-white, shaded ivory, wide center petals tinged Iilac, edged with a minute line of carmine. Fragrant. Very strong, vigorous, tall grower; very free bloomer. Midseason. Unsurpassed by any other midseason white Peony; it should be in every collection. \$1 each; \$10 per doz.

Albert Crousse. Very Iarge, flat, compact bomb. Rose-white; flecked crimson. Fragrant. Tall, erect, free bloomer. Late. Indispensable for cut-flowers. 75 cts. each; $\$ 7.50$ per doz.

Augustine d'Hour. Extremely Iarge, perfect flowers. Color very deep rich brilliant red with slight silvery reflex. TalI, strong grower. \$1 each; \$10 per doz.

Baroness Sehroeder. Rose type. Late. White with shadings of flesh. This is one of the finest Peonies. Its immense flowers of great substance, with high chalice-shaped center, are freely produced, lasting a long time. Very fragrant. \$1 each; \$10 per doz.

Couronne d'Or. White with yellow tints arising from a few stamens showing amidst the petals; center petals tipped with carmine. Large, rather full flower, of superb form. Strong grower and very free bloomer. Good keeper. Late. 75 cts. each; $\$ 7.50$ per doz.

Edulis Superba. Large, Ioose, flat crown. Bright mauve-pink, collar mixed with narrow lilac petals. Fragrant. Early. Strong, upright, free bloomer. The best pink for Memorial Day. $50 \mathrm{cts}$. each; $\$ 5$ per doz.

Felix Crousse. Large, globular, typical bcmb. Brilliant red. Fragrant. Strong, vigorous grower, medium height, free bloomer. One of the best red varieties. \$1 each; $\$ 10$ per doz.
Festiva Maxima. Very large, globular, rose type. Pure white center prominently flecked crimson; outer petals sometimes faint lilac-white on first opening. Very tall, strong, vigorous grower. Early. $65 \mathrm{cts}$. each; $\$ 6.50$ per doz.

Fragrans. Very showy variety of solferino red. Very freeblooming and an old favorite. Late. $75 \mathrm{cts}$. each; $\$ 7.50$ per doz.

Karl Rosenfield. Very Iarge, globular, compact, semi-rose type. Dark crimson. Very strong, tall, compact grower and free bloomer. Midseason. A brilliant and striking variety. A prize-winner. $\$ 1.50$ each; \$15 per doz.

Mme. Calot. Very large rose type. Pale hydrangea-pink, center shaded darker, collar tinted silver. Gocd fragrance. TaII, strong grower; free bloomer. 65 cts. each; $\$ 6.50$ per doz.

Mme. Dueel. Large, globular flower of bright silvery pink, with salmon shading and silvery reflex. Fragrant. Strong grower of medium height. $\$ 1$ each; $\$ 10$ per doz.

Mons. Krelage, Very Iarge, medium, compact high crown. Pale lilac-rose; coliar lighter, shaded amber-yellow at the base. Good fragrance. Medium height, strong growth. Early. \$1 each; \$10 per doz.

President Taft. A vigorous, strong grower and a profuse bloomer, every shoot being crowned by a big bloom. The flower is really of enormous size; there may be Peony flowers as large, but none larger. The color is a delicate hydrangea-pink, completely enveloped in a halo of angelic white. The fragrance is delicious. It is certainly a glorious, gorgeous flower, very large and double. \$2.50 each; \$25 per doz.

Rubra Superba. Large, rose type. Deep carmine-crimson. Fragrant. Medium height. Very late. $75 \mathrm{cts}$. each; $\$ 7.50$ per doz.

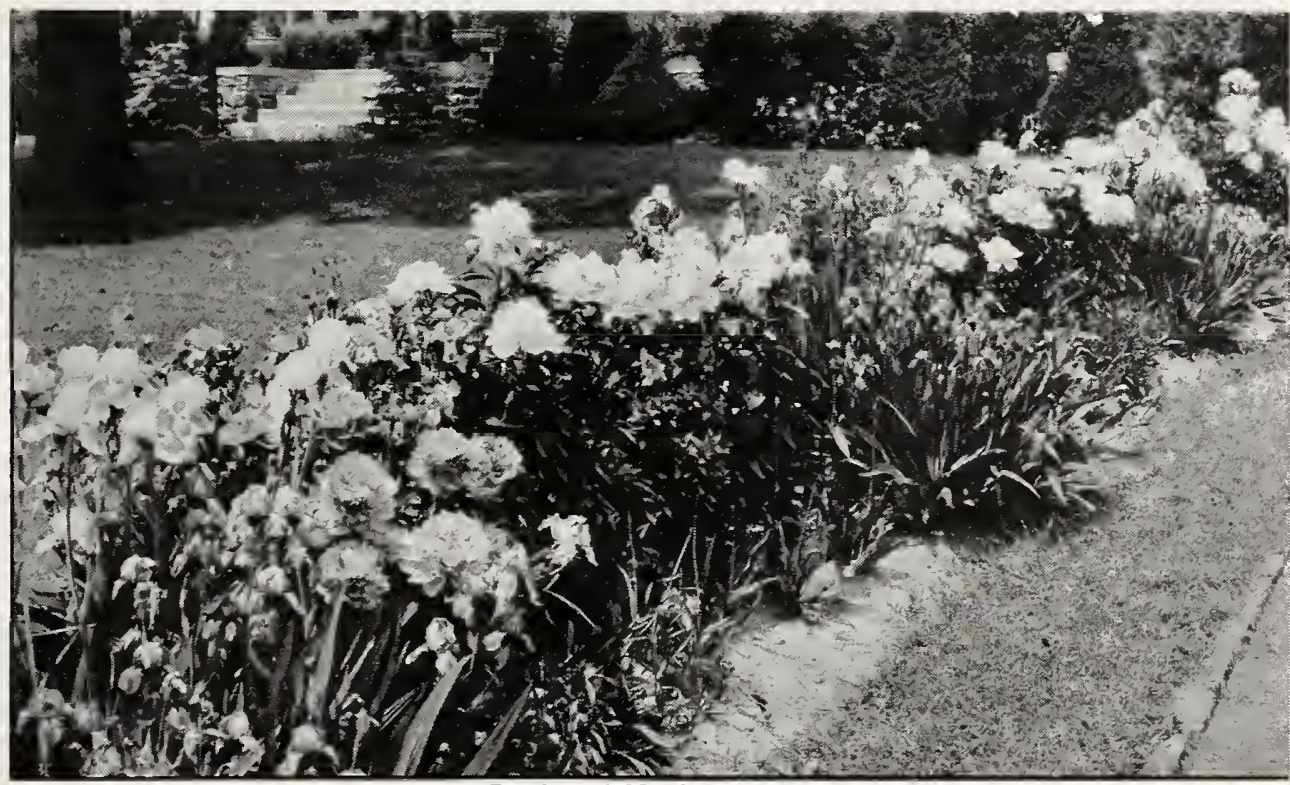

Border of Hardy Peonies 


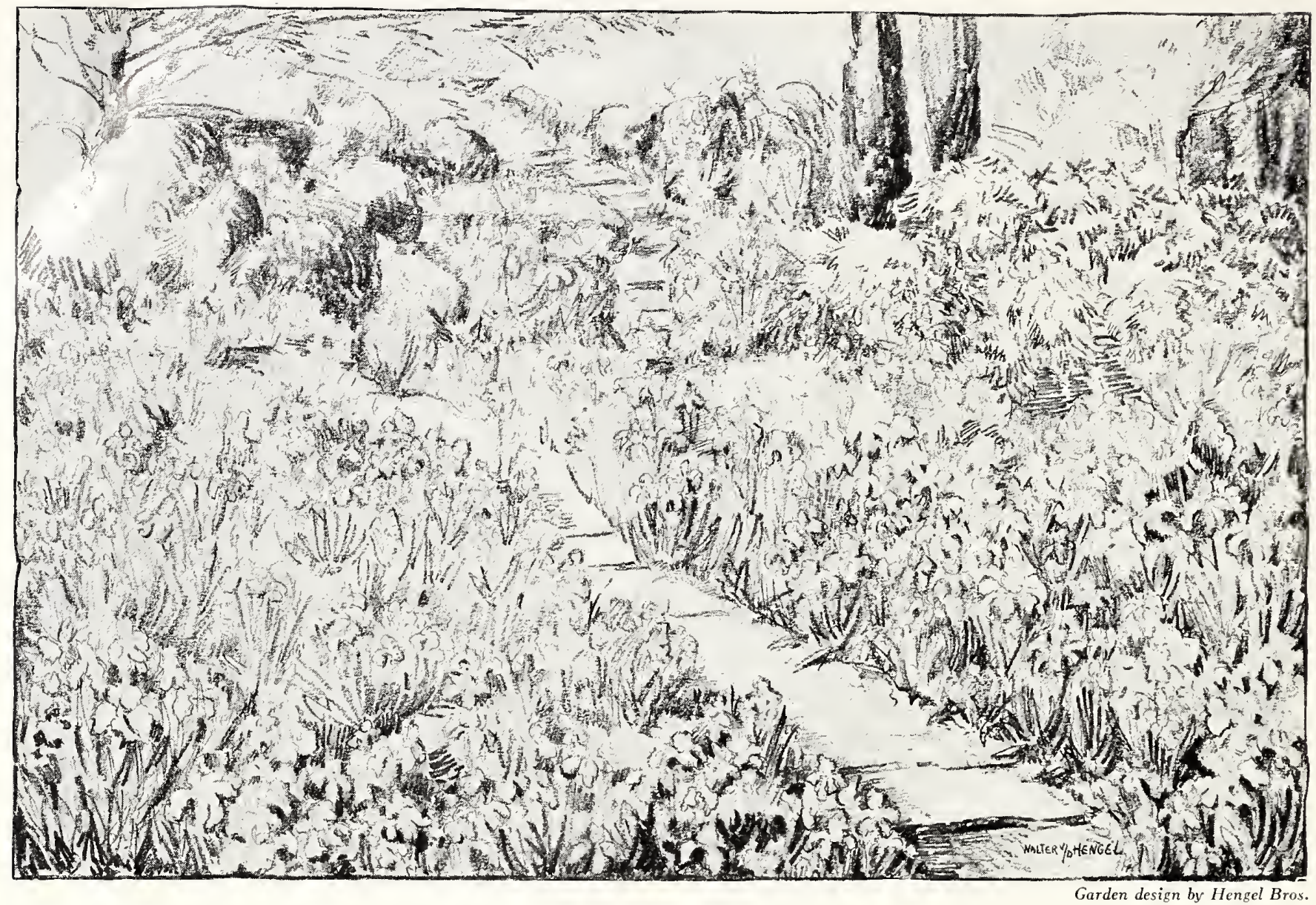

\section{Iris germanica (German Iris)}

This class of Irises, as we all know, is very easily grown, freeflowering and drought-rcsisting, and there is not a garden where a few clumps could not be used to the greatest advantage. They have been greatly improved the last few years and therefore we offer cnly some of the latest introductions. S., standards; F., falls.

Ambassadeur. One of the finest. S., deep lavender, suffused with bronze; F., maroon with purplish cast. \$1 each.

Archeveque. S., a rich shade of reddish purple; F., dark velvety purple. Very free-flowering. $50 \mathrm{cts}$. each.

Ballerine. A superb variety. Flowers porcelain-blue, with broad, rounded, wavy margins; F., slightly deeper in color; deliciously scented $\$ 1$ each.

Cluny. A lovely, very large flower. S., wisteria-blue; F., bluish violet, with deeper shadings. Very free. $\$ 1$ each.

Magnifica. All that its name implies. F., a superb dark reddish purple; S., light violet-blue. \$1 each.

Moliere. S. light blue, overlaid brown; F., purplish maroon, merging lighter at the edges. $\$ 1$ each.

Monsignor. Richly colored and very free. S., pale violet-purple; F., overlaid and reticulated with deep purple. $21 / 2 \mathrm{ft}$. $50 \mathrm{cts}$ each.

Raffet. S., intense violet-blue; F., dark violet, reticulated with white and violet in the upper portion. $50 \mathrm{cts}$. each.

\section{Iris Kaempferi (Japanese Iris)}

The Japanese Irises come into bIoom after the German Irises have finished, and thercfore it is well to plant some of both in order to get a succession of bloom. The flowers of the varieties listed are of immense size and wonderful colorings, Good for cutting if taken before bud opens.

Gekka-no-Nami. Six very large, creamy white, drooping petals. $\$ 1$ each.

Gold Bound. Large, double, pure white flowers with yellow centers. $50 \mathrm{cts}$. each

Helen Von Siebold. Reddish violet, vcined white. Three petals. $50 \mathrm{cts}$. each.

Kohadi. Gravish white, with amaranth center, veined dark blue. Three petals. $50 \mathrm{cts}$. each.

Kuma-fungeki. Purple-blue, stigmas lighter; long crange bars. $\$ 1$ each.

Kumo-no-Obi. Lavender-blue. Six petals. \$1 each.

Kuro-kumo. Double. Purple overlaid with dark blue, yellow blotches; stignias dark blue bordered purple. $\$ 1$ each.

Pyramid. Violct-blue; white veins through center of petals. Six petals. \$1 each.

Shiga-no-Uranami. Beautiful double pale blue flowers. 75 cts. each.

Victor. White, veined violet-blue, purple center. Six petals. 50 cts. each; $\$ 5$ per doz.

\section{Shrubs}

ACER palmatum atropurpureum. Blood-leaf Japonese Maple. Strong plants, $11 / 2$ to $2 \mathrm{ft}$. high, $\$ 6$ to $\$ 7.50$ each.

CARYOPTERIS mastacanthus (incana). Blue Spireo. A small, late-blooming shrub with misty blue flowers in clusters. 25 cts. each; $\$ 2.50$ per doz.

KOLKWITZIA amabilis. Beauty Busb. A charming, rare shrub covered with bright pink flowers in spring. Exceedingly graceful. Fine plants from pots. \$1.50 each.

\section{Vines}

AMPELOPSIS veitchi. Boston Ivy. Close-clinging wall vine and creeper. Gcod in shade. $50 \mathrm{cts}$. each.

CLEMATIS henryi. Large, claret flowers. \$1 each.

Jackmani. Fine purple bloom. \$1 each.

Mme. Edouard Andre. Red. \$1 each.

Paniculata. White, misty flowers. $50 \mathrm{cts}$. each.

HEDERA helix. Englisb Iv. Rich green creeper. $50 \mathrm{cts}$. each. 


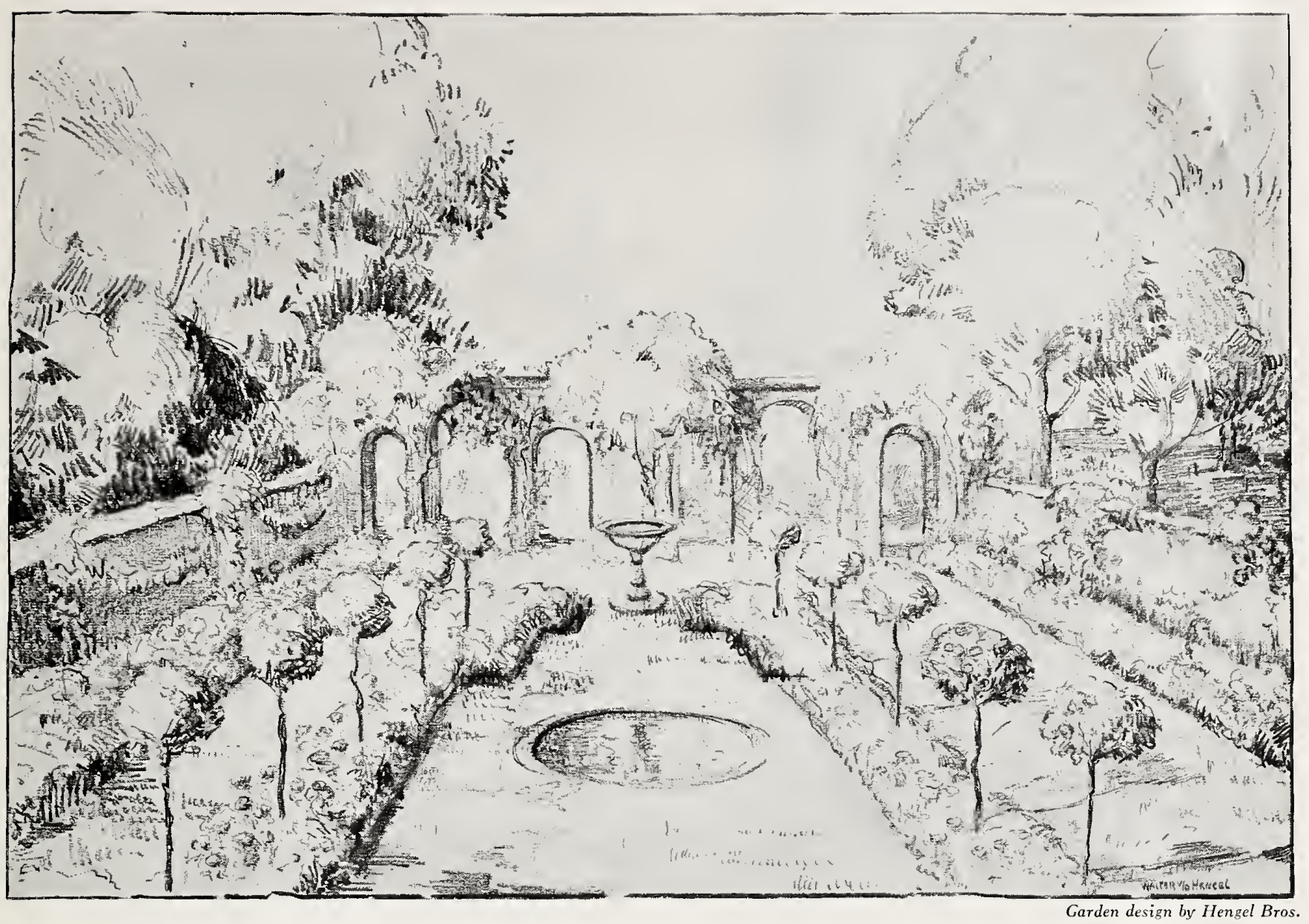

\section{Roses}

The Rose is the queen of all cultivated flowers and by far the most popular amongst the garden-loving public by virtue of the charming individuality of its flowers.

The best and most effective way of planting Roses is in masses, either in separate beds or borders or in specially constructed Rose-gardens, for here we can make use of them all: the beautiful everblooming Hybrid Tea and Tea Roses, the stronger growing Hybrid Perpetuals, the dainty and showy Baby Rambler, and the lovely hardy climbers, trailing over arches or trcllises. IV'hen properly laid out and planted with the right varieties, such a garden will be a source of pleasure from early June until latc fall, but it is during this first month, when all Roses burst into their full glory, that we behold a picture never to be forgotten. The number of commercial varieties of Roses is very large, and we selected the varieties offered below as some of the most satisfactory and useful for garden planting in this section of the country. They are all strong, healthy plants, potted up during the winter months, and can be planted any time after the ground is warm enough without any danger of check to the plants, provided they are taken out of the pots carefully without breaking the ball of earth containing the roots. The main thing to remember in planting Roses is to give them a well-prepared, rich, deep dug soil and plenty of water during hot, dry wcather.

\section{Everblooming Hybrid Tea and Tea Roses}

\section{All Roses $\$ 1$ each, $\$ 11$ per doz., unless otherwise noted}

Betty. A very free-blooming, beautiful Rose. Its exquisitely formed buds of a coppery pink open to large, buff-pink flowers. A great favorite.

Betty Uprichard. A pretty combination of colors-inner face of petals delicate salmon-pink to carmine, with coppery sheen and orange suffusion. Well-formed, medium-sized flowers of good substance and sweet-scented.

Briarcliff. Vivid, clear pink. Pointed bud. Hardy grower.

Chateau de Clos Vougeot. Brilliant scarlet, shaded red; very double; fragrant.

Columbia. The well-known bright pink, sweet-scented Rose. It is very free-blooming and has lovely shaped flowers. Excellent for cutting.

Constance. A free-flowering variety, producing beautiful, long, orange-yellow buds, developing into full, globular, golden yellow flowers.
Dame Edith Helen. (New.) This is, without a doubt, one of the finest outdoor Roses introduced lately. The growth is strong and vigorous, producing long-pointed buds, opening into wonderful, perfectly formed, full, double flowers of a brilliant rose-pink color; delightfully scented.

Duchess of Wellington. Although not a new variety, it is still near the top in the class of yellow Roses. It makes a lovely pointed bud, changing from deep orange-yellow to light Icmonyellow as the flower opens, and is very fragrant.

Edel. Bold, sturdy growth. White with ivory shading.

Eldorado. Marechal-Niel-yellow; very fragrant. Free-flowering Etoile de Hollande. Brilliant crimson-red; moderately large blooms. Vigorous and free-flowering.

Hadley. A lovely Rose of a beautiful velvety rich crimson, sweetly scented. Although the flowers are somewhat small during the hot weather, they are in fine form in the fall. A great favorite. 


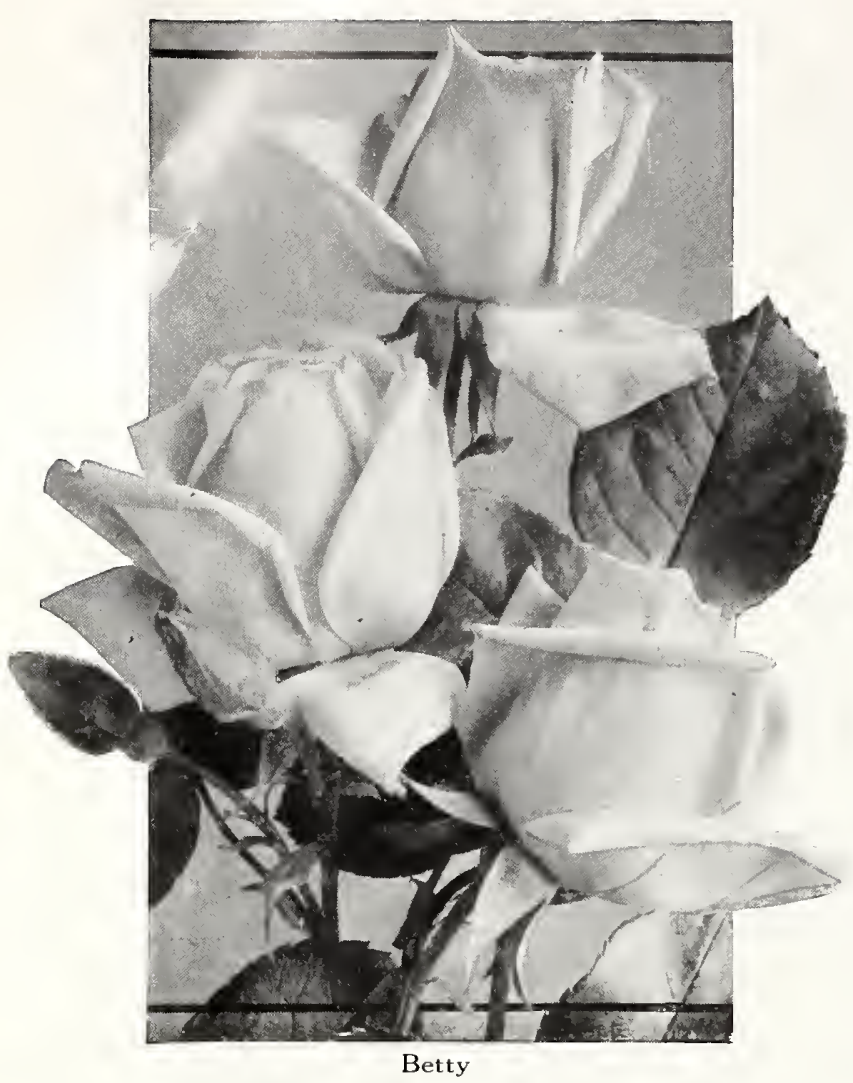

HYBRID TEA AND TEA ROSES, continued

Hoosier Beauty. A magnificent flower of a rich deep red and very fragrant.

Imperial Potentate. Oval buds, opening into fragrant, double, rose-pink flowers. Free-flowering.

Independence Day. Another of those outstanding Roses of unique coloring, being of a rich orange-apricot, suffused with sunflower-yellow and delightfully fragrant.

Jonkheer J. L. Mock. A truly grand Rose of enormous size, cleep rose-pink, offset with a silvery hue. Similar to the old La France. The buds open very slowly and therefore are fine for cutting.

Kaiserin Auguste Viktoria. An old variety, but still one of the best. The flowers are of the purest white, of most lovely shape, and rather fragrant. Free-flowering.

Lady Hillingdon. Rich, deep yellow, becoming lighter as the flowers open. Very lovely and free-flowering.
HYBRID TEA AND TEA ROSES, continued

Lady Margaret Stewart. (New.) A wonderful, very sweetscented, full, double Rose of excellent form, and a pleasing, deep sunflower-yellow, splashed with orange-scarlet, while the reverse of the petals is deeply suffused with carmine. $\$ 1.50$ each.

Louise Catherine Breslau. A beautiful Rose, producing large, full flowers of a lovely shrimp-pink color, shaded ceppery orange and yellow.

Miss Cynthia Forde. One of the best outdoor Roses. Rich pink flowers, perfectly shaped, double, and fragrant.

Miss Rowena Thom. Recent introduction (1928). Flowers brilliant rose-pink, base of petals suffused yellow. Buds long and shapely; very fragrant. $\$ 1.50$ each.

Mme. Butterfly. Beautiful buds; soft pink, tinted yellow. Free and sweet-smelling.

Mme. Edouard Herriot. One of the most showy and brilliant Roses in existence and stands out amongst any collection of Roses. The color we can best describe as a fiery orange-red and salmon. Very free-flowering.

Mme. Jules Bouche. Best white ever-blooming Rose yet introduced. Flowers large, of splendid form, fragrant. Fine grower.

Mrs. Aaron Ward. Indian-yellow shading lighter. Very floriferous; strong grower.

Mrs. A. R. Barraclough. Soft, brilliant carmine-pink, with yellow at base of petals. Bud long and well-shaped; fragrant.

Mrs. Charles Bell. Lovely shell-pink with salmon shadings; sweetly scented.

Mrs. Erskine Pembroke Thom. The best yellow bedding Rose to date. Dark bronze foliage. Shapely buds and full, double flowers. $\$ 1.25$ each.

Norman Lambert. A distinct color-mixture of deep chromeyellow, shading to orange-scarlet and burnt-orange. Flowers medium size. Free-blooming. $\$ 1.50$ each.

Padre. One of the best bedding Roses of recent introduction. A strong-growing, very free-flowering variety, producing beautiful, long, pointed buds of a brilliant coppery scarlet, flushed with yellow.

Premier. Very Iarge, fragrant flowers of a rich deep pink. Very popular greenhouse variety but also an excellent garden Rose.

Radiance. Large, deep rose-pink, globular flowers, on strong stems, making them excellent for cutting.

Red Radiance. Being a sport of the foregoing, it has practically the same habits, only the color is a deep red. These are two of the most popular Roses in this country and produce good results almost anywhere.

Rev. F. Page-Roberts. Rose of great beauty in form and colorcoppery red, opening to golden yellow. Vigorous and branching habit. $\$ 1.50$ each.

Souvenir de Claudius Pernet. Bright yellow, deepening toward center. This Rose has become very popular with the public in a short time, it being of a color everyone is looking for, with beautiful dark green, glossy foliage, and very free-blooming. $\$ 1.50$ each: \$15 per doz.

Souvenir de Georges Pernet. Another glorious Rose of very high merit. It is a very large, brick-red flower with carmine and yellow shadings, very double and deliciously fragrant. In every respect a wonderful Rose.

Sunburst. Bloom of intense shade of orange and golden yellow, very fragrant and of good shape. Very striking and beautiful.

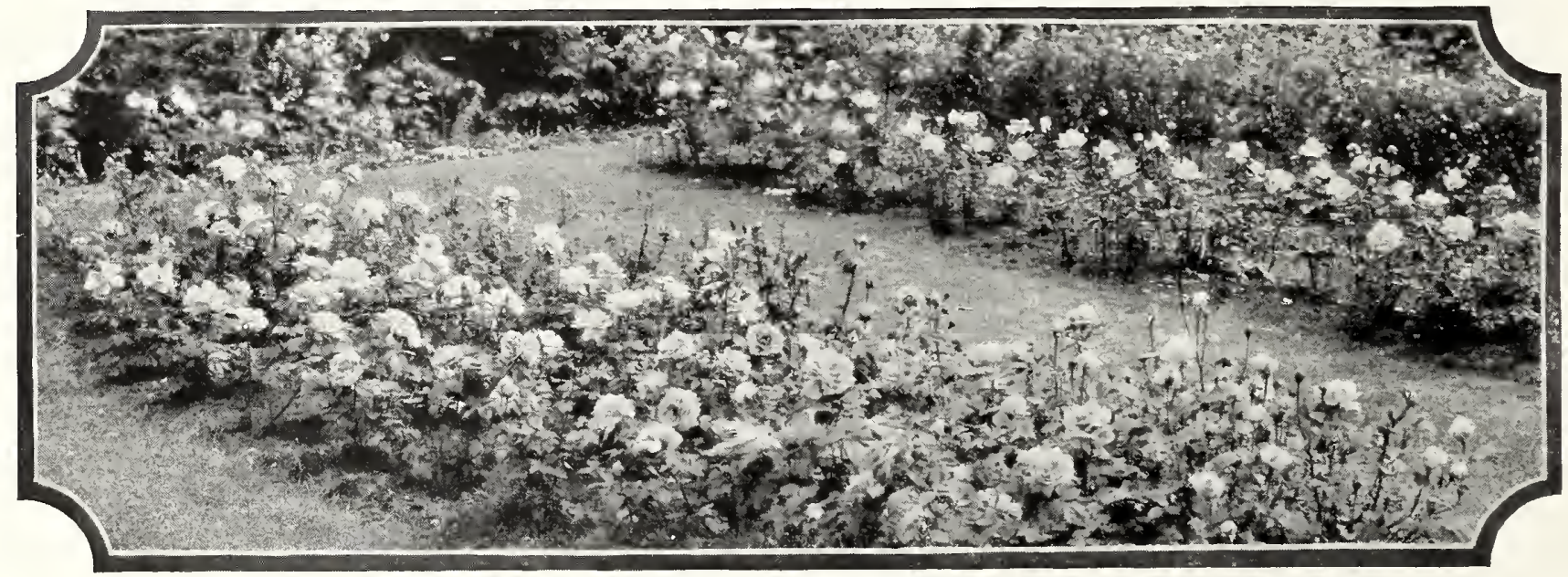

Bed of Hybrid Tea Roses 
HYBRID TEA AND TEA ROSES, continued

Talisman. The sensational Rose of 1929 introduction. A blend of gold, apricot, pink, and old-rose. Strong grower. Glossy foliage. Donble. \$2 each.

Ville de Paris. Rich, pure buttercup-yellow; fairly double. Strong grower of upright habit; good bloomer.

Wilhelm Kordes. Rich capucine-red and golden salmon. Buds long and pointed. Habit vigorous, compact. $\$ 1.50$ each.

Willowmere. Coral-red, opening to rich shrimp-pink, shaded yellow. Full, handsone flowers.

\section{Climbing Roses}

Dr. W. Van Fleet. One of the very best of the climbers, being of a beautiful, rich flesh-pink, as large and shapely as a Hybric Tea Rose. Fine for cutting.

Flower of Fairfield. A very fine and recommendable variety of a brilliant crimson color.

Gardenia. Yellow buds and creamy flowers, with rich yellow centers. A very beautiful rambler.

Hiawatha. A wonderful showy variety, with clusters of large single flowers of a brilliant ruby-carmine, with white eye and a mass of golden stamens.

Paul's Scarlet Climber. Produces a great abundance of semidouble flowers of good size; vivid scarlet, shaded with crimson, making this Rose stand out amongst the other ramblers for its exceedingiy brilliant effect.

Silver Moon. Large, semi-double, pure white flowers, produced on strong-growing canes with dark green, glossy foliage.

\section{Shrub Roses}

Rosa Hugonis. Makes a beautiful and most striking plant, with branches 6 to 8 feet long, completely covered with very fragrant, single yellow Roses about 2 inches across. Fine for planting in shrubbery borders.

Soleil d'Or. Large, double, golden yellow and nasturtium-red flowers. Very handsome.

Wichuraiana. Good for banks. Pure white, single flowers. Forms dense mats of evergreen foliage. $75 \mathrm{cts}$. each.

All Roses in foregoing lists, $\$ 1$ each, $\$ 11$ per doz., unless therwise noted

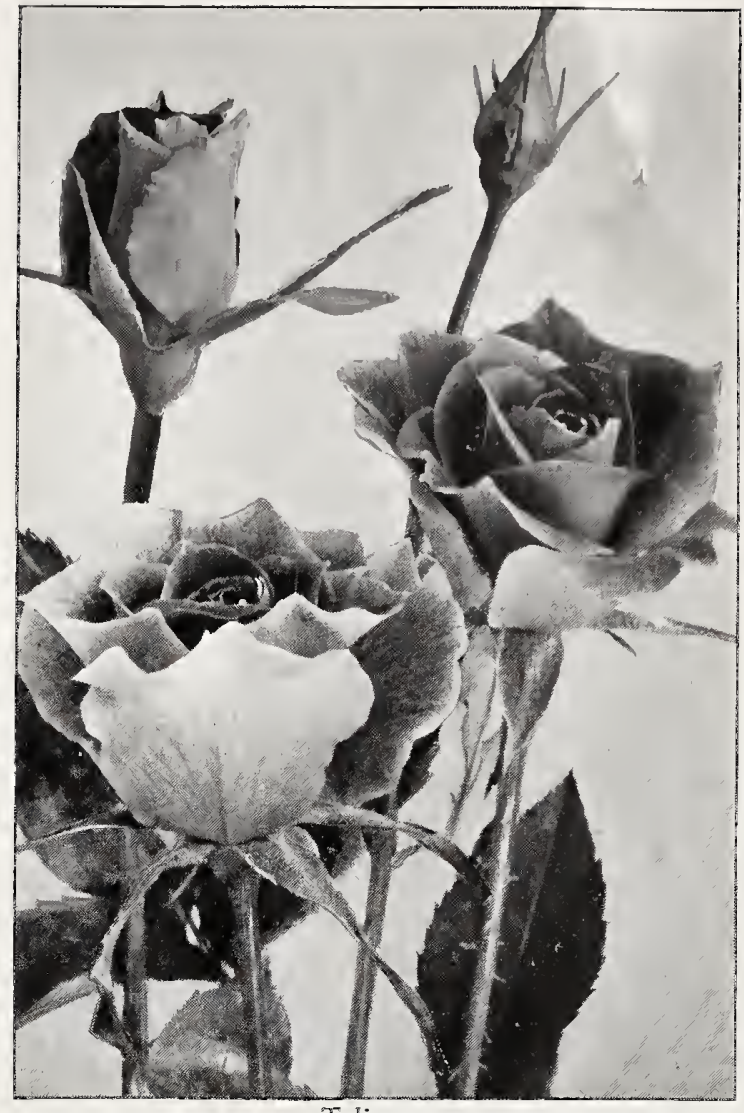

Talisman

We are specialists in making designs and plans for Rose-gardens adapted to any location and extensive or small estates. One of our Rosengarden designs is reproduced on page I5

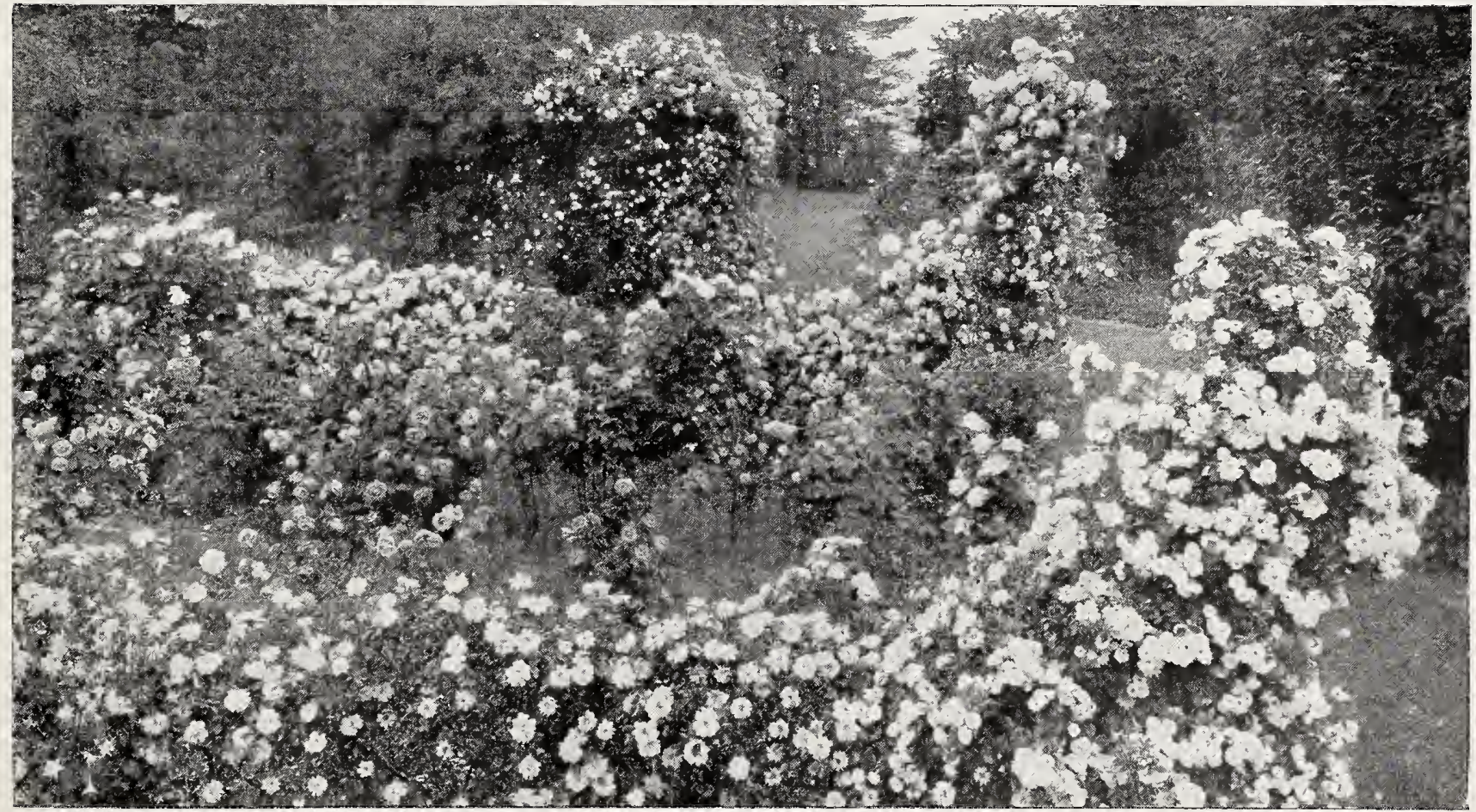

Climbing Roses 


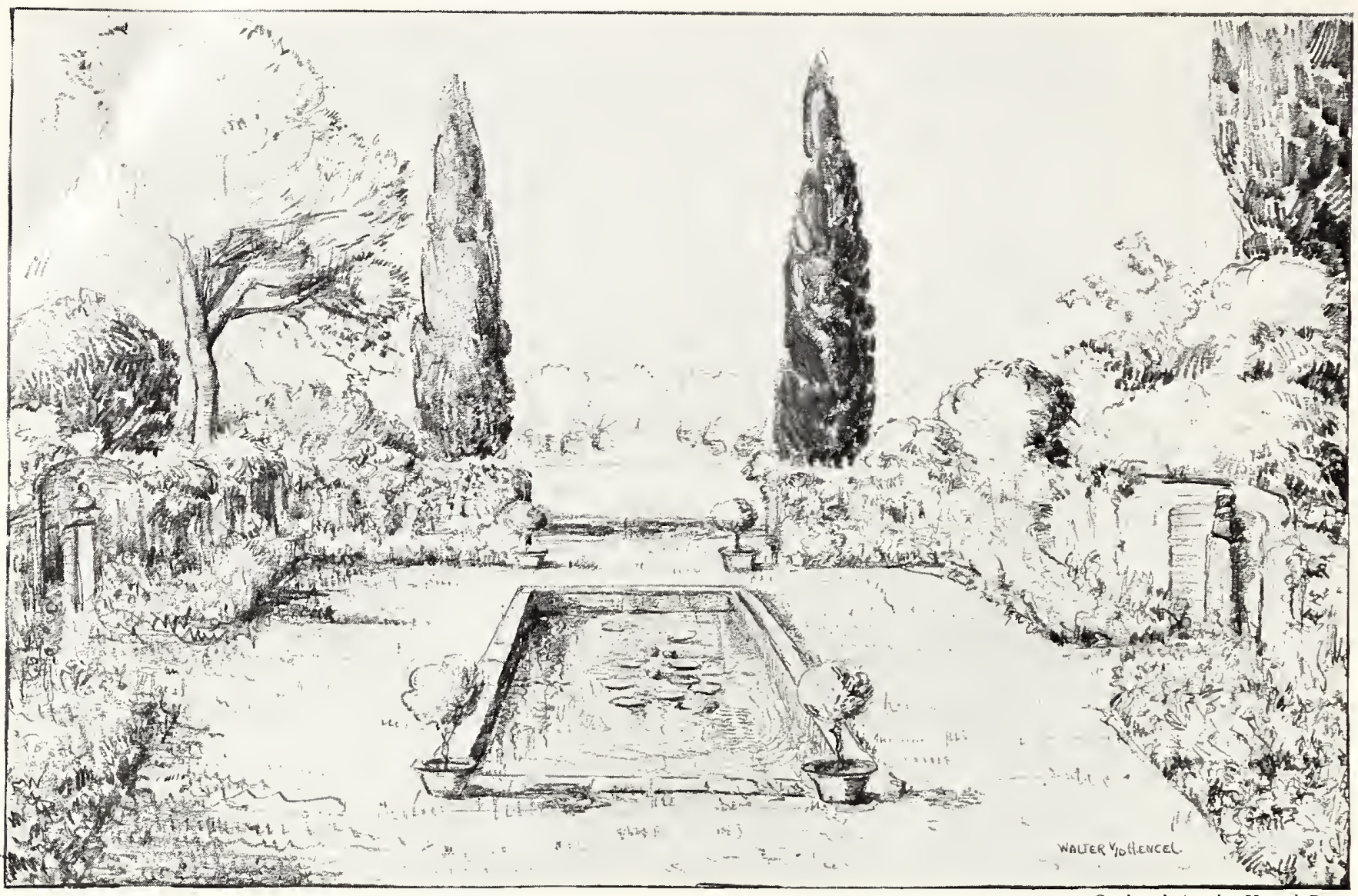

Garden design by Hengel Bros.

\section{Evergreens}

The coniferous Evergreens are especially desirable for this permanent green foliage which makes them even more beautiful in winter than in summer because of their contrast with the bare branches of deciduous trees and shrubs. They are used largely for specimens or accents, at prominent places in the garden and are frequently massed to provide soft, permanent backgrounds for the rock-garden and perennial border.

Almost all varieties have definite conventional shapes which adapt them to formal and architectural uses, but if left untrimmed many assume a wild grace which makes them eminently suitable companions for the untamed beauties which are the rarest treasures of the rock-garden. Our Evergreens are specially selected for their beaty of form and color and are grown to the proper size and shape for most effective use.

JUNIPERUS chinensis pfitzeriana. Pfizer's Juniper. One of the

hardiest and most useful evergreens for foundation planting.

It makes a low-spreading tree of irregular form and has

plume-like, gray-green branches. 2 to $21 \%$-ft. spread . . . . \$5 00 $21 / 2$ to 3 -ft. spread 800 3 to $31 / 2$-ft. spread. 1200

Communis depressa plumosa. Purple Spreading Juniper. A beautiful, low-growing, very hardy, spreading Juniper. Excellent for use in rock-gardens as well as for planting at base of other evergreens. The foliage is plume-like of a soft silvery green, turning a beautiful rich purple in the fall and through the winter.

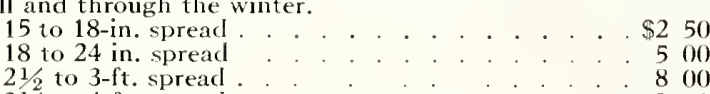

$31 \%$ to 4-ft. spread 1200

Communis hibernica. Irish Juniper. A slender, uprightgrowing tree of beautiful form with glaucous green foliage. Excellent for formal work. 18 to 24 in. high
2 to $21 / 2 \mathrm{ft}$. high .
$21 / 2$ to $3 \mathrm{ft}$ high
3 to $31 / 2 \mathrm{ft}$. ligh

Excelsa stricta. Spinv Greck Juniper. A fine, compact-growing tree of conical shape with glaucous green foliage. Good for formal and foundation plantings.

15 to 18 -in. spread . . . . . . . \$3 00

18 to 24 in. spread . . . . . . 400

2 to $2 \frac{1}{2}-\mathrm{ft}$. spread 600

Juniperus Sabina horizontalis. A creeping Juniper with bluish green foliage. Fine for rockwork.

15 to 18 -in. spread . . . . . . \$300

18 to 24 in spread

$21 / 2$ to 3 -ft. spread. . 750

Virginiana. Red Cedar. Talı, slender-growing trees. This variety is adapted for planting anywhere for creating height effect.

6-ft. spread ............ \$9 00 8 -ft. spread 1200 9 to 10 -ft. spread . $\quad 1500$ 10 to $12-\mathrm{ft}$ spread 1800

Virginiana glauca. Silver Cedar. A lovely, upright-growing tree like foregoing, but the young growth is silvery white, later changing to blue.

3 to $31 / 2 \mathrm{ft}$. high . . . . . . . . . $\$ 1000$

$31 \frac{1}{2}$ to $4 \mathrm{ft}$. high

PICEA excelsa. Norwav Spruce. A well-known tree of great hardiness. Good for lawn planting.

2 to $21 / \mathrm{ft}$. high . . . . . \$3 . . \$300

2 to $21 / 2 \mathrm{ft}$ high $\cdots \cdots \cdots$ 3 to $4 \mathrm{ft}$. high $\quad 500$

Pungens Kosteri. Koster's Blue Spruce. Beautiful, soft blue color.

2 to $21 / 2 \mathrm{ft}$. high . . . . . . . . . . . $\$ 1250$

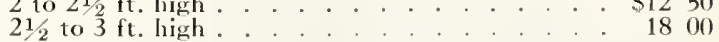

PINUS sylvestris. Scotcb Pine. A rapid-growing Pine of uneven, picturesque habit, with silvery green needles.

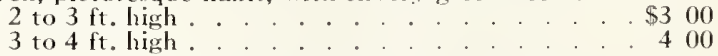




\section{EVERGREENS, continued}

PYRACANTHA coccinea Ialandi. 5 to $6 \mathrm{ft}$. Conspicuously berried shrub. Very unusual.

Specinicns . . . . \$12 to $\$ 1500$ Small, 18 to 24 in., pot-grown . . . 400

RETINOSPORA pisifera. Sawara Cypress. A tall, pyramidal. growing tree, with flattened deep glowing green branches. 2 to $21 / 2 \mathrm{ft}$. high. . . . . . . . \$4 00 $21 / 2$ to $3 \mathrm{ft}$, high

3 to $31 / \mathrm{ft}$ high

500

Pisifera aurea. Like the foregoing, but with bright golden yellow foliage.

2 to $2 \frac{1}{2} \mathrm{ft}$. high . . . . . . . . . . . . $\$ 400$

$21 / 2$ to $3 \mathrm{ft}$ high. . . . . . . 500

Plumosa. Plume Cypress. Tall, pyramidal tree with feathery foliage. Shear every year to keep it thick and shapely.

15 to $18 \mathrm{in}$. high

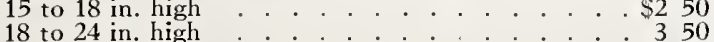

2 to $21 / 2 \mathrm{ft}$ high . . . . : 450

$21 / 2$ to $3 \mathrm{ft}$ high . . . . . . . . . 600

3 to $31 / 2 \mathrm{ft}$. high . . . . . . . . . . . 750

Plumosa argentea. Silver-tipped Plume Cypress. Of upright, pyramidal form. Foliage dark green with white tips.

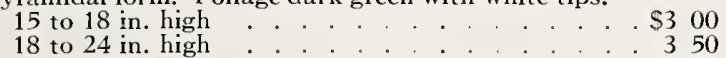

2 to $21 / 2 \mathrm{ft}$. high ......... 500

Plumosa aurea. Golden Plume Cypress. The bright golden form of the foregoing, and of the same habit.

15 to 18 in. high

18 to 24 in. high

2 to $21 / 2 \mathrm{ft}$. high . . . . . . . . 500

$21 / 2$ to $3 \mathrm{ft}$ high. . . . . . . . . . . . . . . 700

3 to $31 / 2 \mathrm{ft}$. high 'Duarf Ýllow Plume Cypress A very

Plumosa lutescens. Dwarf Yellow Plume Cypress. A very compact-growing variety, forming broad, round-topped form, without any shearing.

10 to 12 in. high ........... . . \$3 00

12 to $15 \mathrm{in}$. high . . . . . . . . 400

15 to 18 in. high 600

Squarrosa veitchi. Moss Cypress. A beautiful evergreen of pyramidal form, with very dense, feathery foliage, of a silvery blue, retaining this color throughout the year.

15 to $18 \mathrm{in}$. high

18 to $24 \mathrm{in.} \mathrm{high}$

2 to $21 / 2 \mathrm{ft}$. high

$\$ 300$

$21 / 2$ to $3 \mathrm{ft}$. high

400

750

THUYA occidentalis, American Arborvitæ. Pyramidal tree with light green, flat foliage.

2 to $21 / 2 \mathrm{ft}$. high . . . . . . . . . . \$2 50

$21 / 2$ to $3 \mathrm{ft}$ high . . . . . . . 300

$31 / 2$ to $4 \mathrm{ft}$. high . . . . . . . . . . . . . . . . . 400

ccidentalis, Columbia. Columbia Arborvitx. Forms beautiful trees of narrow, pyramidal form with silver-tipped branches. $11 / 2$ to $2 \mathrm{ft}$. high, $\$ 3$ each.

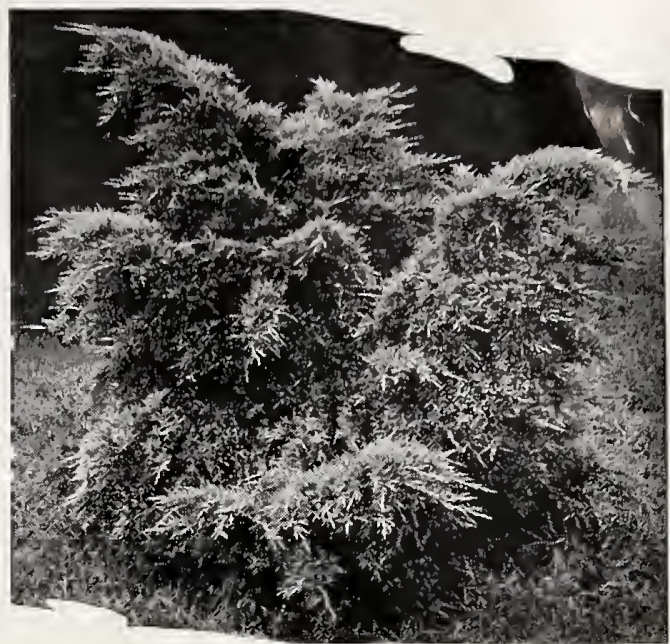

Juniperus pfitzeriana

Thuya occidentalis ellwangeriana. Tom Thumb Arborvitx. A cone-shaped tree, broad at the base, dense habit, and soft texture. Bright green, turning purple in winter.

15 to 18 in. high

$\$ 250$

18 to 24 in. high 400

2 to $2 \frac{1}{2} \mathrm{ft}$. high . . . . . 500

$21 / 2$ to $3 \mathrm{ft}$. ligh. 600

Occidentalis ericoides. Heatb Arborvitx. A lovely, very densegrowing tree of very soft texture. Fine for formal work and foundation planting.

12 to 15 in. high . . . . . \$2 50

15 to 18 in. high $\ldots \ldots$

18 to 24 in. high $21 \frac{1}{2}$ to high 2.500

Occidentalis globosa hoveyi. Hovev's Globe Arborvitx. Slow and compact-growing, of oval shape, with bright green foliage. Excellent for front of foundation plantings.

10 to 12 in. high

12 to 15 in. high

18 to 24 in. high

Orientalis aurea nana. Berckman's Golden Arborvitæ. Popular for foundation planting. Dwarf and very slow-growing; bright goiden color. $11 / 2$ to $2 \mathrm{ft}$. high, $\$ 4$ each.

Orientalis elegantissima. Yellow Columnar Arborvita. A beautiful, stately, narrow pyramidal-growing tree, of bright golden color in summer, changing to bronze in winter.

18 to 24 in. high . . . . . . . . . . \$500 18 to $24 \mathrm{in}$. high

Specimen trees of Retinospora, Thuya, and Biota, 7 to $10 \mathrm{ft}$. high, for immediate effect. Prices on application

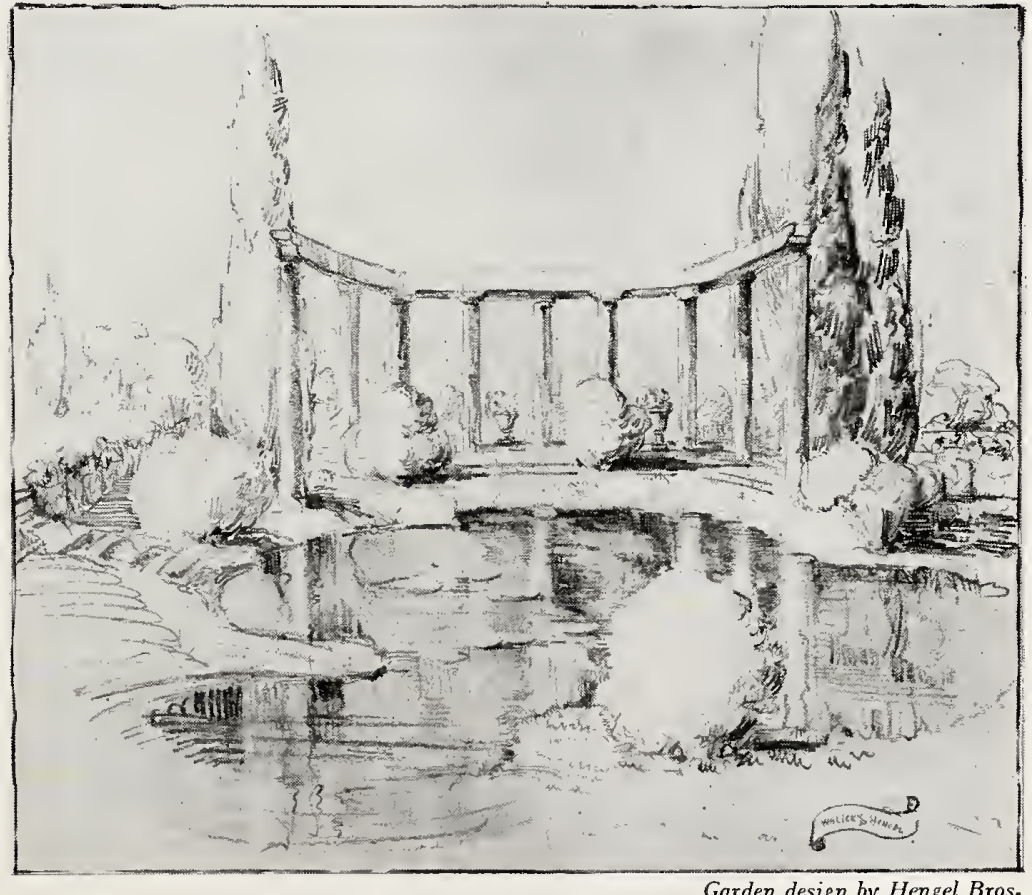

Garden design by Hengel Bros. 


\section{Broad-leaved Evergreens}

Excellent shrubs which carry their glossy, rich green foliage throughout the year. Among them the Azaleas and Rhododendrons are remarkable for their exceedingly handsome flowers and are most desirable for mass planting. AII of them like a peaty, gritty soil with perfect drainage, and will not endure lime. Most of them grow well in partially shaded places or complete shade.

AUCUBA japonica. Large, lustrous, often variegated foliage and

bright red berries in the autumn. Each

$$
12 \text { to } 15 \text { in. . . . . . . . . . . . . . . . . . . . . . . . . . . } 18 \text {. } 3200
$$

AZALFA amœena. Spreading, bushy shrub, densely covered in ing with vivid claret-colored blossoms.

10 to 12 in.

. $\$ 150$ 12 to 15 in.

250

Calendulacea. Flame Azalea. Although this is not an evergreen Azalea, it is, nevertheless, a fine variety to use in combination with rhododendrons and other broad-leaved evergreens. The flcwers are Iarge, of brick-red, orange, and yellow shadings, in late May. A wonderfully showy plant. 1 to $2 \mathrm{ft}$.

2 to $3 \mathrm{ft}$.

$\$ 300$

Hinodegiri. The most popular of the hardy Azalcas, and is a blaze of fiery red flowers in early spring.

10 to 12 in.

$\$ 200$

Hinamoyo. Most chaming shrub, covered with lovely. shell-pink flowers. 10 to 12 in., $\$ 2.50$ each.

Kaempferi hybrida. Here we have a new race of Hardy Azaleas surpassing anything yet introduced. They are wonderful, strong-growing plants and perfectly hardy. The large, richly colored flowers make a magnificent display during May and June. We offer beautiful strong plants, 18 to $24 \mathrm{in}$. high, in separate colors at $\$ 12$; large specimens, $\$ 15, \$ 20$, and $\$ 25$.

Macrantha. Large, single, salmon-red flowers in great profusion. One of the most effective of all. 18 to 24 in., $\$ 6$ each.

Yodogawa. Beautiful, double flowers of lilac and lavender later than most varieties.

12 to $15 \mathrm{in.}$

$\$ 350$

18 to $24 \mathrm{in}$.

600

DAPHNE cneorum. Garland Flower. Handsome dwarf evergreen subshrubs, forming long, procumbent branches, with bright pink, sweetly scented flowers. Bloom in April and again in September.

8 to 10 in.

10 to 12 in.

Each

250

12 to 15 in.

400

KALMIA latifolia. Mountoin Laurel. Fine for massing with rhododendrons. Very showy, with masses of white and pinkflowers in late May. Fine, bushy specimen plants. 18 to 24 in. high . . . . . . . . . . \$1 50 2 to $3 \mathrm{ft}$. high

3 to $4 \mathrm{ft}$. high

250

500

LAUROCERASUS officinalis schipkaensis. Cberry Laurel. A hardy, evergreen shrub with thick, glossy, dark green, pointed leaves. 15 to 18 in. 18 to 24 in.
LEIOPHYLLUM BUXIFOLIUM. Sand Mrrtle. A very handsome, low-growing, evergreen shrub, excellent for use in rock-gardens. It his thick, dark green, oval leaves, very much like boxwood, and flowers in May and June on slender pedicles, white with pinkish tint outside.

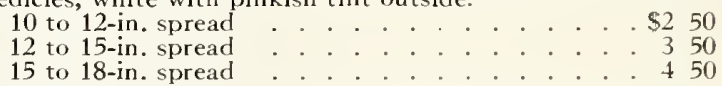

LEUCOTHOE catesbæi. Drooping Leucotboe. A graceful, lowgrowing plant having large, glossy green leaves on arching branches. Large spikes of small white flowers in spring and the leaves turn a beautiful bronze in autumn. 2 to $21 / 2 \mathrm{ft}$., $\$ 3$.

PIERIS floribunda. Mountoin Andromeda. Deep green foliage and clusters of white flowers in May. Good for partly shaded positions. 2 to $3 \mathrm{ft}$. high, $\$ 3.50$ each.

\section{Boxwood}

BUXUS sempervirens. Useful for formal edging and windowboxes. 12 to 15 in., 85 cts. each; $\$ 9$ per doz.; $\$ 75$ per 100 . Sempervirens suffruticosa. True Dwarf Box. Very slow and compact-growing. The best variety to use for bordering garden walks and beds. $\quad$ Each $10 \quad 100$

5 to $6 \mathrm{in.} \mathrm{.} \mathrm{.} \mathrm{.} \mathrm{.} \mathrm{.} \mathrm{.} \mathrm{.} \mathrm{.} \$ 035 \$ 400 \$ \$ 3000$

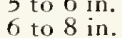
6 to 8 in.
8 to 10 in. $\begin{array}{lllll}50 & 5 & 50 & 45 & 00 \\ 85 & 9 & 00 & 75 & 00\end{array}$

\section{Rhododendrons}

The Rhododendrons are extensively used for foundaticn planting on the shady side of the house where other evergreens would not do so well. They are also fine material for screening and massing under trees and often are excellent for creating background for rock-gardens. The beautiful, glossy green leaves always show up well, even if the plants are not in flower.

RHODODENDRON Hybrids. We have several varieties of these beautiful, free-flowering hybrid Rhododendrons in such colors as Red, Pink, Purple, and White. $1 \frac{1}{2}$ to $2 \mathrm{ft}$., $\$ 7.50$ and $\$ 10$ each.

Carolinianum. Carolina Rbododendron. Blooms early in May with light rose-pink flowers. Each

$$
2 \text { to } 3 \mathrm{ft} \text {. high.......... . } \$ 450
$$

3 to $4 \mathrm{ft}$ high 600

Catawbiense. Catauba Rbododendron. "Blooms late" in May with large clusters of reddish purple flowers. 2 to $3 \mathrm{ft}$. high. . . . . . . . \$4 . . . . . . 00

3 to $4 \mathrm{ft}$. high .......... . . 500 to 5 ft high

750

Maximum. Great Laurel. This is the best variety for screening and background planting for shady and partly shady positions. Blooms in July with white and blush-pink flowers. 2 to $3 \mathrm{ft}$. high

3 to $4 \mathrm{ft}$. high 4 to $5 \mathrm{ft}$. high 5 to $6 \mathrm{ft}$. high

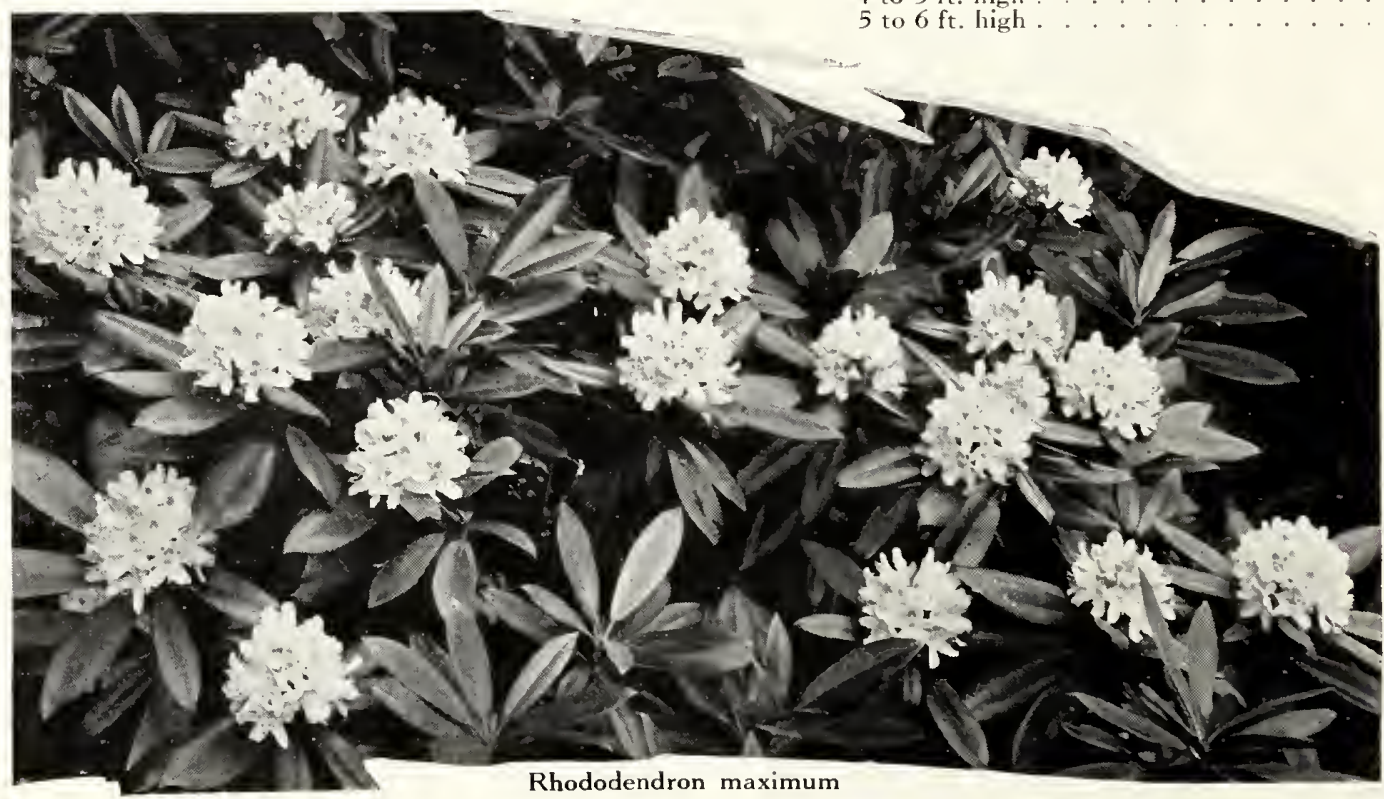

Rhododendron maximum 


\section{Evergreens and Hardy Flowering Shrubs}

We also have an extensive selection of Evergreen Trees and Hardy Flowering Shrubs, and, inasmuch as we do not submit an itemized list of these, we are always glad to quote prices on any particular varieties in these two classes of stock.

\section{Plans and Sketches}

We are at all times willing to submit plans and sketches. In this case we make a flat charge of 10 per cent of the total cost of the job. In event the contract is awarded to our firm, there will be no charge for the same. 


\section{Hengel Bros.}

58-60 Lancaster Ave.

ARDMORE, PENNA.

Nurseries and Greenhouses at King of Prussia, Pa. 